(С) Коллектив авторов, 2021

Никольский А.А. ${ }^{1}$, Шиловский И.П. ${ }^{1}$, Юмашев К.В. ${ }^{1,2}$, Вишнякова Л.И. ${ }^{1}$, Барвинская Е.Д. ${ }^{1}$, Ковчина В.И. ${ }^{1}$, Корнеев А.В. ${ }^{1,2}$, Туренко В.Н. ${ }^{1}$, Каганова М.М. ${ }^{1,2}$, Брылина В.Е. ${ }^{2}$, Никонова А.А., Козлов И.Б. ${ }^{1}$, Кофиади И.А. ${ }^{1}$, Сергеев И.В. ${ }^{1}$, Маерле А.В. ${ }^{1}$, Петухова О.А. ${ }^{1}$, Кудлай Д.А. ${ }^{1,3}$, Хаитов М.Р. ${ }^{1,4}$

\title{
Влияние локального подавления экспрессии
} гена Stat3 на нейтрофильное воспаление легких

\section{в экспериментальной модели на мышах}

\begin{abstract}
Федеральное государственное бюджетное учреждение «Государственный научный центр «Институт иммунологии» Федерального медико-биологического агентства, 115522, г. Москва, Российская Федерация 2 Федеральное государственное бюджетное образовательное учреждение высшего образования Московская государственная академия ветеринарной медицины и биотехнологии - МВА имени К.И. Скрябина Министерства сельского хозяйства Российской Федерации, 109472, г. Москва, Российская Федерация

Федеральное государственное автономное образовательное учреждение высшего образования Первый Московский государственный медицинский университет имени И.М. Сеченова Министерства здравоохранения Российской Федерации (Сеченовский Университет), 119991, г. Москва, Российская Федерация

${ }^{4}$ Федеральное государственное автономное образовательное учреждение высшего образования «Российский национальный исследовательский медицинский университет имени Н.И. Пирогова» Министерства здравоохранения Российской Федерации, 117997, г. Москва, Российская Федерация
\end{abstract}

\section{Резюме}

Введение. Бронхиальная астма (БА) - это хроническое воспалительное заболевание дыхательных путей. Длительное время считалось, что БА развивается исключительно по Th2-зависимому механизму, однако к настоящему времени выделяют несколько фенотипов заболевания, один из них - нейтрофильная БА. У таких пациентов болезнь характеризуется резистентностью к стандартной терапии глюкокортикостероидами, определяя необходимость создания новых способов терапии. Нейтрофильное воспаление легких при БА протекает по ИЛ-6/STAT3-зависимому механизму, что делает компоненты этого сигнального пути перспективными терапевтическими мишенями. Один из способов, посредством которого можно регулировать экспрессию генов, - это интерференция РНК.

Цель данного исследования - оценить эффекты локального подавления экспрессии гена Stat3 на модели нейтрофильной БА у мышей.

Материал и методы. На фоне развития признаков нейтрофильной БА мышам ингаляционным способом вводили комплекс молекул малых интерферирующих РНК (миРНК) и пептида-носителя. После курса ингаляций у животных оценивали степень выраженности основных проявлений БА: уровень аллерген-специфических антител, изменение гиперреактивности бронхов, клеточный состав бронхоальвеолярного лаважа (БАЛ), гистопатологические изменения в легких.

Результаты. Осуществлен дизайн 5 вариантов молекул миРНК против гена Stat3 и в экспериментах in vitro показано, что вариант siSTAT3-1426 в 5 раз снижал экспрессию целевого гена. Создан комплекс молекул миРНК и пептида-носителя LTP, который подавлял экспрессию генов Stat3 и Ill7a в Th17-лимфоцитах. В исследованиях in vivo на модели нейтрофильной БА у мышей показано, что 3-кратное ингаляционное введение этого комплекса приводило к подавлению экспрессии гена Stat3 в клетках БАЛ в 2 раза и, как следствие, к ослаблению Тh17-иммунного ответа, а в итоге - к 3-кратному снижению инфильтрации легких нейтрофилами и восстановлению толщины стенок бронхов.

Заключение. Создан комплекс молекул миРНК, направленных против гена Stat3, и пептида-носителя, ингаляции которым приводят к уменьшению Th17-зависимого нейтрофильного воспаления легких в модели нейтрофильной БА у мышей. Применение созданного комплекса может быть многообещающим подходом к терапии нейтрофильной кортикостероид-резистентной БА.

Ключевые слова: нейтрофильная бронхиальная астма; РНК-интерференция; Stat3 
Для цитирования: Никольский А.А., Шиловский И.П., Юмашев К.В., Вишнякова Л.И., Барвинская Е.Д., Ковчина В.И., Корнеев А.В., Туренко В.Н., Каганова М.М., Брылина В.Е., Никонова А.А., Козлов И.Б., Кофиади И.А., Сергеев И.В., Маерле А.В., Петухова О.А., Кудлай Д.А., Хаитов М.Р. Влияние локального подавления экспрессии гена Stat3 на нейтрофильное воспаление легких в экспериментальной модели на мышах. Иммунология. 2021; 42 (6): 600-614. DOI: https://doi.org/10.33029/0206-4952-2021-42-6-600-614

Финансирование. Исследование выполнено при финансовой поддержке РФФИ в рамках научного проекта № 20-34-90151

Конфликт интересов. Авторы заявляют об отсутствии конфликта интересов.

Nikolskii A.A. ${ }^{1}$, Shilovskiy I.P. ${ }^{1}$, Yumashev K.V. ${ }^{1,2}$, Vishniakova L.I. ${ }^{1}$,

Barvinskaia E.D. ${ }^{1}$, Kovchina V.I. ${ }^{1}$, Korneev A.V. ${ }^{1,2}$, Turenko V.N. ${ }^{1}$,

Kaganova M.M. ${ }^{1,2}$, Brylina V.E. ${ }^{2}$, Nikonova A.A. ${ }^{1}$, Kozlov I.B. ${ }^{1}$, Kofiadi I.A. ${ }^{1}$, Sergeev I.V. ${ }^{1}$, Maerle A.V. ${ }^{1}$, Petukhova O.A. ${ }^{1}$, Kudlay D.A. ${ }^{1,3}$, Khaitov M.R. ${ }^{1,4}$

\section{Effect of local suppression of Stat3 gene expression} in a mouse model of pulmonary neutrophilic inflammation

\footnotetext{
${ }^{1}$ National Research Center - Institute of Immunology, Federal Medical-Biological Agency of Russia, 115522, Moscow, Russian Federation

${ }^{2}$ Moscow State Academy of Veterinary Medicine and Biotechnology - MVA named after K.I. Skryabin of the Ministry of Agriculture of the Russian Federation, 109472, Moscow, Russian Federation

3 I.M. Sechenov First Moscow State Medical University of the Ministry of Health of the Russian Federation (Sechenov University), 119991, Moscow, Russian Federation

${ }^{4}$ N.I. Pirogov Russian National Research Medical University (RNRMU) of the Ministry of Health of the Russian Federation, 117997, Moscow, Russian Federation
}

\section{Abstract}

Introduction. Bronchial asthma (BA) is a chronic inflammatory disease of the airways. For a long time, it was believed that BA developed exclusively according to the Th2-dependent mechanism, however, to date, several phenotypes of the disease have been distinguished, one of which is neutrophilic BA. Neutrophilic BA is characterized by resistance to standard corticosteroid therapy, that need to search for new way of treatment. Neutrophilic inflammation of the lungs is developed under activation of IL-6/STAT3-pathway, that makes the molecular components of this pathway to be the promising targets. One of the technologies by which genes expression can be regulated is RNA interference.

The aim of this study was to evaluate the effects of local suppression of Stat 3 gene expression in a mouse model of neutrophilic BA.

Material and methods. During the development of BA features mice were inhaled with a complex of small interfering RNA (siRNA) and a carrier peptide. After the course of inhalations, the severity of BA manifestations was assessed: the level of allergen-specific antibodies, changes in bronchial hyperreactivity, the cellular composition of the bronchoalveolar lavage (BAL) fluid, histopathological alterations in the lungs.

Results. 5 variants of siRNA against Stat 3 gene were designed. In vitro experiments established that the variant siSTAT3-1426 significantly ( 5 times) reduced the expression of the target gene. A complex of siRNA and a carrier peptide LTP down-regulated the expression of Stat3 and $1 l 17 a$ genes in Th17-lymphocytes. In vivo studies in a mouse model of neutrophilic BA revealed, that the inhalations with the complex led to a 2-fold inhibition of Stat3 gene expression in BAL fluid cells, 3-fold decrease in neutrophilic infiltration of the lungs and recovery of the thickness of the airway walls.

Conclusion. The complex of siRNA targeted to Stat3 gene and the carrier peptide was developed. The inhalations with the complex decreased Th17-dependent neutrophilic inflammation of the lungs in neutrophilic BA model in mice, that can be a promising approach to the therapy of neutrophilic corticosteroid-resistant BA.

Keywords: neutrophilic bronchial asthma; RNA interference; Stat3 
For citation: Nikolskii A.A., Shilovskiy I.P., Yumashev K.V., Vishniakova L.I., Barvinskaia E.D., Kovchina V.I., Korneev A.V., Turenko V.N., Kaganova M.M., Brylina V.E., Nikonova A.A., Kozlov I.B., Kofiadi I.A., Sergeev I.V., Maerle A.V., Petukhova O.A., Kudlay D.A., Khaitov M.R. Effect of local suppression of Stat3 gene expression in a mouse model of pulmonary neutrophilic inflammation. Immunologiya. 2021; 42 (6): 600-14. DOI: https://doi. org/10.33029/0206-4952-2021-42-6-600-614 (in Russian)

Funding. The study was supported by RFBR, project number 20-34-90151.

Conflict of interests. The authors declare no conflict of interests.

\section{Введение}

Бронхиальная астма (БА) - это гетерогенное хроническое воспалительное заболевание дыхательных путей [1]. За последние десятилетия резко выросло количество больных БА; в отдельных странах заболеваемость достигает 15-18 \% [2]. В России общее число больных БА приближается к 10 млн человек, что составляет около 7 \% населения [3]. Стандартная терапия БА предусматривает применение кортикостероидов, ингибиторов лейкотриенов и бронходилататоров, которые снижают выраженность проявлений заболевания у значительной доли пациентов [1]. Успешно применяют аллерген-специфическую иммунотерапию [4], но она имеет свои ограничения (опасность возникновения нежелательных явлений, невозможность применения у пациентов с неаллергической БА) [5].

Длительное время считалось, что БА развивается исключительно по Th2-зависимому механизму, в котором центральную роль играют Тh2-клетки, продуцирующие провоспалительные цитокины интерлейкин(ИЛ)-5, ИЛ-4 и ИЛ-13, активность которых приводит к формированию основных проявлений БА (эозинофильное воспаление легких, гиперреактивность бронхов, ремоделирование дыхательных путей и пр.) [6].

К настоящему времени БА рассматривается как гетерогенное заболевание, включающее несколько фенотипов, один из них - нейтрофильная БА [7]. У пациентов с такой формой астмы воспаление легких связано с инфильтрацией дыхательных путей другими провоспалительными клетками - нейтрофилами. Болезнь, как правило, протекает тяжело и характеризуется резистентностью к стандартной терапии глюкокортикостероидами [8]. Все это создает необходимость разработки новых способов терапии этой патологии. Исследования клеточных и молекулярных механизмов патогенеза данного фенотипа установили взаимосвязь степени тяжести БА и нейтрофильного воспаления легких, которое коррелировало с активацией Тh17-иммунного ответа, а также с повышенным содержанием ИЛ-17А, ИЛ-17F и ИЛ-8 в мокроте [9].

Стоит отметить, что поляризация иммунного ответа в сторону Th2-клеток происходит при активации сигнального пути ИЛ-4/STAT6 [6], тогда как Th17-клетки формируются при активации сигнального пути ИЛ-6/ STAT3 $[10,11]$. В свою очередь Тh17-клетки секретируют цитокины ИЛ-17А, ИЛ-17F, ИЛ-21 и ИЛ-22, которые приводят к развитию проявлений БА: нейтрофильному воспалению легких, гиперсекреции слизи и ремоделированию респираторного тракта [12]. Учитывая это, компоненты сигнального пути ИЛ-6/STAT3 являются перспективными биомишенями для разработки новых лекарственных средств терапии кортикостероид-резистентной БА.

Появляются новые способы регуляции активности генов, например основанные на интерференции РНК. Они заключаются в использовании молекул малых интерферирующих РНК (миРНК), способных сиквенс-специфично деградировать мРНК целевых генов, включая гены, вовлеченные в воспаление легких [13]. Главная проблема, затрудняющая использование молекул миРНК, сложность их доставки в клетки-мишени [14]. Для доставки миРНК к месту их биологического эффекта применяют так называемые векторы, липосомы [15], полимеры и пептиды $[16,17]$. В данном исследовании изучались антивоспалительные свойства комплекса, состоящего из молекул миРНК, направленных против гена, кодирующего STAT3, и катионного пептида LTP, на модели нейтрофильной БА у мышей [18].

\section{Материалы и методы}

Проектирование и синтез миРНК. При помощи программного обеспечения OligoWalk (http://rna.urmc. rochester.edu/cgi-bin/server_exe/oligowalk/oligowalk_ form.cgi) были спроектированы последовательности миРНК, направленные к гену Stat3 мыши (табл. 1) [19]. Синтез осуществлен с использованием автоматического синтезатора Oligo Pilot 10 (Cytiva, США).

Скрининг активности миРНК in vitro. Для скрининга активности миРНК in vitro в 24-луночный планшет засевали 100 тыс. клеток L929 (фибробласты мыши) в полной питательной среде DMEM (Gibco, США) [10 \% фетальной бычьей сыворотки (Biosera, Филиппины), 2 \% буферного раствора HEPES («ПанЭко», Россия), 0,1 \% антибиотика гентамицина (Gibco, США), 0,6 \% L-глутамина («ПанЭко», Россия)] и инкубировали 1 сут при $37{ }^{\circ} \mathrm{C}$ в $\mathrm{CO}_{2}$-инкубаторе до достижения $75 \%$ конфлюэнтности. Затем заменяли среду на бессывороточную DMEM (Gibco, США) [2 \% буферного раствора HEPES, 0,1 \% антибиотика гентамицина, 0,6 \% L-глутамина]. Трансфекцию 1 мкг миРНК против гена Stat3 проводили в бессывороточной среде OРTIMEM (Gibco, США) при помощи трансфекционного агента Lipofectamine 2000 (Invitrogen, США), объем смеси составлял 100 мкл. В качестве контроля также трансфецировали миРНК к гену Gfp (green fluorescent protein). Приготовленную смесь выдерживали 15 мин при 
Таблица 1. Варианты миРНК, направленных против гена Stat3

\begin{tabular}{|c|c|c|c|}
\hline миРНК & Последовательность & $\begin{array}{c}\text { Предсказанная } \\
\text { эффективность, \% }\end{array}$ & $\begin{array}{c}\text { Сходство с другими } \\
\text { генами мыши, \% }\end{array}$ \\
\hline siSTAT3-465 & UUUCUGUUCUAGAUCCUGCtt & 96 & 84 \\
\hline siSTAT3-930 & UAAGUUUCUGAACAGCUCCtt & 94 & 84 \\
\hline siSTAT3-1426 & UAUACCACAGGAUUGAUGCtt & 94 & 79 \\
\hline siSTAT3-1826 & UUGCUGCUCUCGCUGAAGCtt & 95 & 84 \\
\hline siSTAT3-2492 & UUAUCACCCACACUCACUCtt & 96 & 84 \\
\hline
\end{tabular}

комнатной температуре и вносили в лунки с монослоем клеток. Клетки инкубировали при $37{ }^{\circ} \mathrm{C}$ в $\mathrm{CO}_{2}-$ инкубаторе. Через 4 ч в каждую лунку добавляли 50 мкл $10 \%$ фетальной бычьей сыворотки (ФБС) (Biosera, Филиппины). После этого клетки инкубировали при $37{ }^{\circ} \mathrm{C}$ в $\mathrm{CO}_{2}$-инкубаторе в течение 24 ч. Затем из лизатов клеток выделяли тотальную РНК и анализировали экспрессию мРНК Stat3.

Исследование активности комплекса миРНК/ пептид in vitro. Проведено исследование активности комплекса, состоящего из миРНК против гена Stat3 и пептида-носителя LTP (siSTAT3/LTP) в экспериментах in vitro. Активность исследовалась на 2 типах клеток: L929 и Th17-клетках мыши. Для этого клетки L929 засевали в 24-луночный планшет в количестве 100 тыс. клеток на лунку в 600 мкл полной питательной среды DMEM (Gibco, CШA). Накануне трансфекции клетки инкубировали 1 сут при $37{ }^{\circ} \mathrm{C}$ в $\mathrm{CO}_{2}$-инкубаторе до достижения $75 \%$ конфлюэнтности. Перед внесением трансфекционной смеси в лунках с клетками заменяли полную питательную среду DMEM на бессывороточную среду DMEM. Смесь трансфекционного агента общим объемом 100 мкл, состоящего из миРНК против гена Stat3 или Gfp (в качестве контроля) (1, 2 и 4 мкг), а также пептида LTP $(12,5 ; 25$ и 50 мкг соответственно), готовили в бессывороточной среде ОРТIMEM (Gibco, США). В качестве еще одного контроля использовали коммерческий трансфекционный агент Lipofectamine 2000 (Invitrogen, США). Приготовленную смесь выдерживали 15 мин при комнатной температуре и вносили в лунки с монослоем клеток. Клетки инкубировали при $37{ }^{\circ} \mathrm{C}$ в $\mathrm{CO}_{2}$-инкубаторе. Через 4 ч в каждую лунку добавляли 50 мкл $10 \%$ ФБС. После этого клетки инкубировали при $37{ }^{\circ} \mathrm{C}$ в $\mathrm{CO}_{2}$-инкубаторе в течение 24 ч и затем из лизатов клеток выделяли тотальную РНК и анализировали экспрессию мРНК Stat3.

Дополнительно активность комплекса siSTAT3/LTP была изучена на Th17-клетках мыши. Для этого предварительно выделяли наивные Т-лимфоциты из селезенок мышей с помощью клеточной сортировки и индуцировали их дифференцировку в Th17-клетки.

Селезенки отбирали у мышей, умерщвленных методом цервикальной дислокации, и помещали в 12-луночный планшет в 1,5 мл натрий-фосфатного буфера («ПанЭко», Россия) с 3 \% ФБС. Ткань селезенки измельчали и переносили в 15 мл пробирку с 150 мкл коллагеназы (Collagenase from Clostridium histolyticum Type IA 20 мг/мл - Sigma, США) и 150 мкл ДНКазы (Dnase I -
300 ед/мл - Invitrogen, США). Инкубировали на шейкере 30 мин при $37^{\circ} \mathrm{C}$. Затем фильтровали через сито с диаметром пор 40 мкм (Corning, США). Полученную суспензию клеток дважды отмывали 3 мл натрийфосфатного буфера с 3 \% ФБС. Для этого центрифугировали при $300 \mathrm{~g} 7$ мин при комнатной температуре с последующим отбором осадка клеток, который затем ресуспендировали в 3 мл натрий-фосфатного буфера с $3 \%$ ФБС. Далее анализировали на проточном цитометре FACSAria (BD, CША), где из общего пула клеток отбирали только те, которые несли CD4 и CD62L и на которых отсутствовали CD44 и CD25. Эти клетки и представляют собой наивные Т-лимфоциты. Затем клетки помещали в 96-луночный планшет с предварительно (за 4 ч) сорбированными анти-CD3-антителами (10 мкг/мл). Для поляризации наивных Т-лимфоцитов в Th17 добавляли анти-CD28-антитела, ИЛ-6 и трансформирующий фактор роста $\beta$ (ТФР $\beta)$. К контрольным клеткам добавляли только анти-CD28-антитела. Через 72 ч собирали супернатанты и лизаты клеток. Из последних выделяли тотальную РНК и анализировали экспрессию мРНК Ill7a и Stat3.

Установлено, что стимулированные Тh17-клетки характеризовались повышенной экспрессией генов Ill 7 a и Stat3. Кроме того, методом иммуноферментного анализа (ИФА) был выявлен значительный уровень продукции белка ИЛ-17А в супернатантах Th17клеток. Контрольные и стимулированные клетки имели различный фенотип, наблюдаемый при световой микроскопии.

Для изучения активности siSTAT3/LTP Th17-клетки высевали в 24-луночный планшет в количестве 100 тыс. клеток на лунку в 600 мкл полной питательной среды RPMI 1640 (Gibco, CША). Накануне трансфекции клетки инкубировали 1 сут при $37{ }^{\circ} \mathrm{C}$ в $\mathrm{CO}_{2}$-инкубаторе до достижения 75 \% конфлюэнтности. Перед внесением трансфекционной смеси в лунках с клетками заменяли полную питательную среду RPMI 1640 на бессывороточную среду RPMI 1640. Смесь трансфекционного агента общим объемом 100 мкл, состоящего из миРНК против гена Stat3 или Gfp (в качестве контроля) (1, 2 и 4 мкг), а также пептида LTP $(12,5 ; 25$ и 50 мкг соответственно), готовили в бессывороточной среде ОРТІМЕМ (Gibco, CША). В качестве еще одного контроля использовали коммерческий трансфекционной агент Lipofectamine 2000 (Invitrogen, США). Приготовленную смесь выдерживали 15 мин при комнатной температуре и вносили в лунки с монослоем клеток. Клетки инкуби- 
ровали при $37^{\circ} \mathrm{C}$ в $\mathrm{CO}_{2}$-инкубаторе. Через 4 ч в каждую лунку добавляли 50 мкл 10 \% ФБС. После этого клетки инкубировали при $37{ }^{\circ} \mathrm{C}$ в $\mathrm{CO}_{2}$-инкубаторе в течение 24 ч и затем из лизатов клеток выделяли тотальную РНК и анализировали экспрессию мРНК Stat3.

Выделение РНК, обратная транскрипция и количественный ПЦР-анализ. Для количественной оценки уровня экспрессии генов использовали метод количественной полимеразной цепной реакции (ПЦР). Для этого из лизатов клеток выделяли общую РНК набором RNeasy Mini Kit (Qiagen, Германия) согласно протоколу производителя. Для получения комплементарной ДНК (кДНК) РНК подвергали обратной транскрипции с использованием случайных гексамерных праймеров набора ОТ-1 («Синтол», Россия). Затем кДНК амплифицировали на iCycler IQ5 (Bio-Rad, CША) для определения уровня экспрессии генов. В качестве референсного использовали ген $\beta$-актина $(A c t b)$.

Дизайн исследования in vivo. Моделированиенейтрофильной БА проводили на мышах-самках BALB/c в возрасте 6-8 нед, массой 20-22 г, полученных из питомника «Столбовая» ФГБУН НЦБМТ ФМБА России. При поступлении из питомника животные были помещены в карантин на 7 дней, в течение которых проводили ежедневное наблюдение за состоянием животных. При формировании групп в качестве критерия отбора использовали показатель массы тела, так, чтобы индивидуальное значение массы не отклонялось от среднего значения более чем на 10 \%. Все эксперименты на животных проводились в соответствии с принципами Директивы Европейского Союза 2010/63/EU «Законодательство о защите животных, используемых в научных целях» и были одобрены локальным этическим комитетом.

Было сформировано 4 экспериментальные группы. У первых 3 групп индуцировали нейтрофильную БА. Для этого 3-кратно с интервалом в 2 нед внутрибрюшинно вводили 20 мкг аллергена овальбумина (OVA) (Sigma-Aldrich, США) вместе с полным (в 1-й день) и неполным (в 14-й и 28-й дни) адъювантом Фрейнда (FA) (Sigma-Aldrich, США), с последующей аэрозольной провокацией. Через 2 нед после последней иммунизации осуществляли аэрозольную провокацию по 1 ингаляции в день в течение 5 дней смесью 1 мг/мл OVA и 1 мг/мл липополисахарида из E. coli (ЛПС) (SigmaAldrich, США). 4-я группа выступала в качестве контроля, во время сенсибилизации и провокации мыши данной группы подвергались манипуляциям с применением фосфатно-солевого буфера (ФСБ).

На фоне провокаций животным аэрозольно вводили комплекс, содержащий молекулы миРНК против Stat3 и пептид-носитель LTP (siSTAT3/LTP). В качестве контроля аналогичным образом вводили комплекс, содержащий неспецифические молекулы миРНК против гена Gfp и пептид-носитель LTP (siGFP/LTP) (табл. 2). Через 1 сут после последней провокации оценивали гиперреактивность бронхов (ГРБ), а через 2 сут собирали бронхоальвеолярный лаваж (БАЛ) и извлекали легкие для гистологического исследования (рис. 1А).
Определение уровней иммуноглобулинов в сыворотке крови. Через 1 сут после последней аэрозольной провокации аллергеном из ретроорбитального синуса мышей собирали периферическую кровь. Индивидуальные образцы сывороток получали путем центрифугирования при $350 \mathrm{~g}$ в течение 15 мин при комнатной температуре и хранили при $-70{ }^{\circ} \mathrm{C}$ до анализа. Уровни OVA-специфических IgE-, IgG1- и IgG2а-антител в сыворотке измеряли методом ИФА с использованием коммерческих наборов (Becton Dickinson, США).

Определение гиперреактивности бронхов. Использовали прибор для неинвазивной плетизмографии FinePointe NAM (Buxco, США). ГРБ определяли при появлении бронхоспазма у экспериментальных мышей, вызванного аэрозольным введением метахолина (Sigma-Aldrich, США) в возрастающих концентрациях $(6,25 ; 12,5 ; 25$ мг/мл), после чего в автоматическом режиме оценивали удельную сопротивляемость дыхательных путей (ее выражали в см вод. ст. × с / мл) [20].

Отбор образцов бронхоальвеолярного лаважа. Через 2 сут после провокации мышей умерщвляли методом цервикальной дислокации. Дыхательные пути через трахею с помощью шприца промывали дважды 0,5 мл среды RPMI 1640 (Gibco, США), после чего на автоматическом гематологическом анализаторе Abacus Junior Vet (Diatron, Германия) измеряли клеточность БАЛ. Результат выражали в количестве клеток в 1 мл БАЛ. Клетки БАЛ наносили на предметное стекло, дифференциально окрашивали азуром и эозином и подсчитывали количество клеток (макрофагов, нейтрофилов, эозинофилов и лимфоцитов).

Гистологический анализ легких. Через 2 сут после провокации удаляли левое легкое для приготовления микропрепаратов и помещали его в $10 \%$ формалин, обезвоживали путем проводки по спиртам и заливали образцы в парафин. Микротомированием парафиновых блоков получали срезы легких толщиной 2-4 мкм. Полученные препараты окрашивали гематоксилином и эозином (Bio-Optica, Италия) для идентификации эозинофилов, нейтрофилов и лимфоцитов. Гистологическое исследование микропрепаратов легких осуществляли на световом микроскопе (Olympus, Япония). Толщину бронхиального эпителия измеряли в пикселях с использованием микрофотографий ткани легкого при увеличении в 200 раз и программного обеспечения Altami Studio (Альтами, Россия). Анализировали 5 субсегментарных бронхов у каждого экспериментального животного.

Статистический анализ выполняли с применением программного обеспечения Statistica 12.0 (StatSoft inc., США).

\section{Результаты}

Молекулы миРНК сиквенс-специфично подавляют экспрессию гена Stat3 in vitro

С помощью программного обеспечения OligoWalk было спроектировано более 200 вариантов миРНК. 
Таблица 2. Экспериментальные группы и дозы

\begin{tabular}{|l|l|l|l|l|}
\hline \multicolumn{1}{|c|}{ № } & \multicolumn{1}{|c|}{ Группа } & \multicolumn{1}{c|}{ Сенсибилизация } & \multicolumn{1}{c|}{ Провокация } & \multicolumn{1}{c|}{ Введение препарата } \\
\hline 1 & nBA & $\begin{array}{l}20 \text { мкг/мышь OVA } \\
+100 \text { мкл/мышь FA }\end{array}$ & $\begin{array}{l}10 \text { мг/мл OVA } \\
+0,4 \text { мг/мл ЛПС }\end{array}$ & - \\
\hline 2 & siGFP/LTP & $\begin{array}{l}20 \text { мкг/мышь OVA } \\
+100 \text { мкл/мышь FA }\end{array}$ & $\begin{array}{l}10 \text { мг/мл OVA } \\
+0,4 \text { мг/мл ЛПC }\end{array}$ & $\begin{array}{l}1,1 \text { мг/мл } \\
\text { siGFP/b-LTP за 2 ч до введения OVA }\end{array}$ \\
\hline 3 & siSTAT3/LTP & $\begin{array}{l}20 \text { мкг/мышь OVA } \\
+100 \text { мкл/мышь FA }\end{array}$ & $\begin{array}{l}10 \text { мг/мл OVA } \\
+0,4 \text { мг/мл ЛПC }\end{array}$ & $\begin{array}{l}1,1 \text { мг/мл } \\
\text { siSTAT3/b-LTP за 2 ч до введения OVA }\end{array}$ \\
\hline 4 & Контроль & ФСБ & ФСБ & - \\
\hline
\end{tabular}
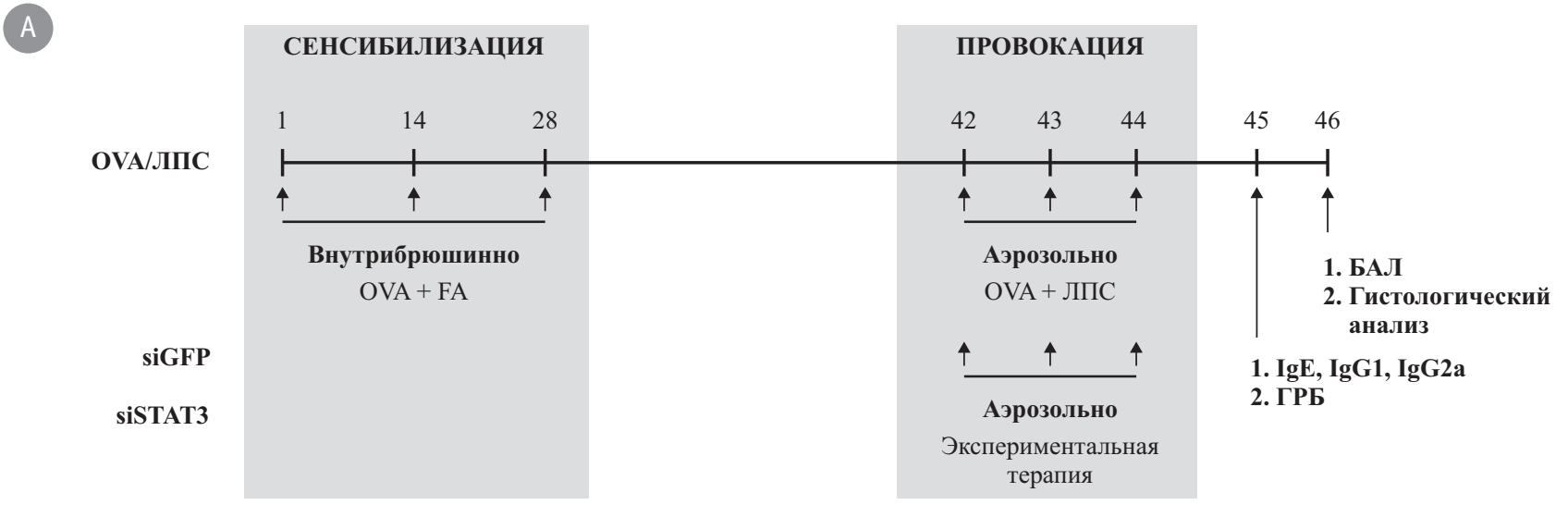

(5)

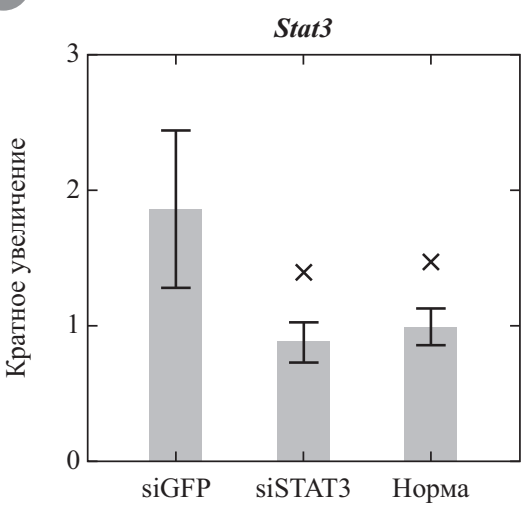

IgE

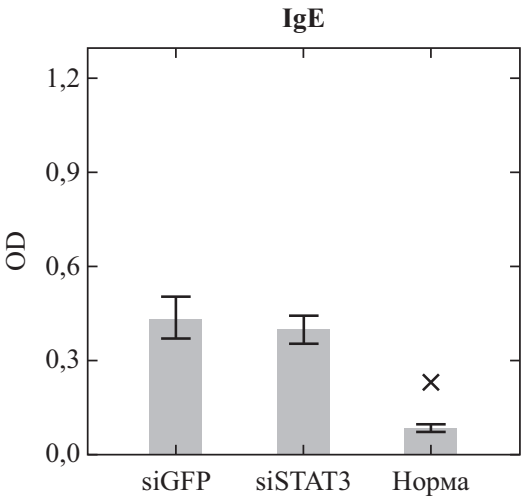

B

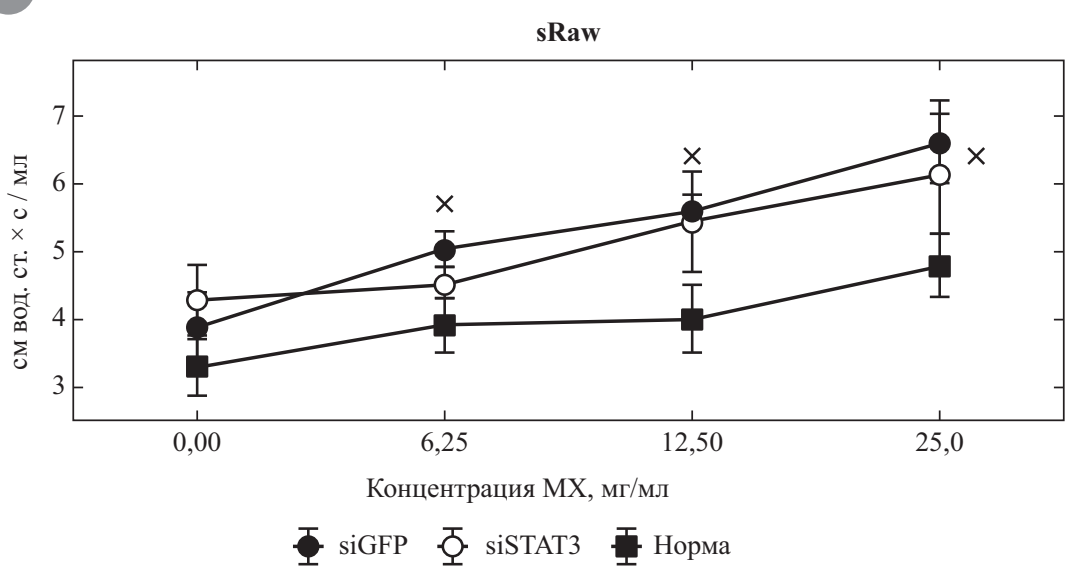

IgG2a

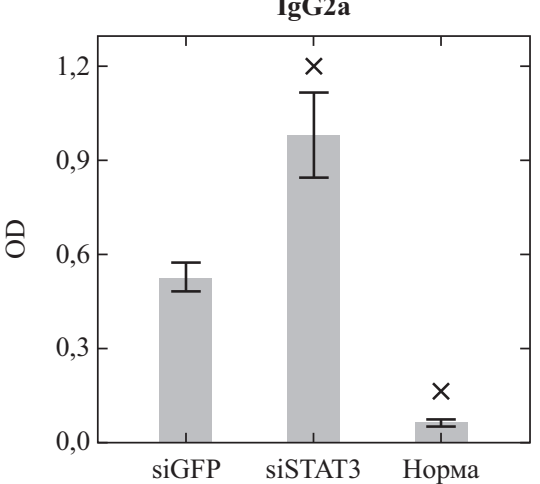

IgG1

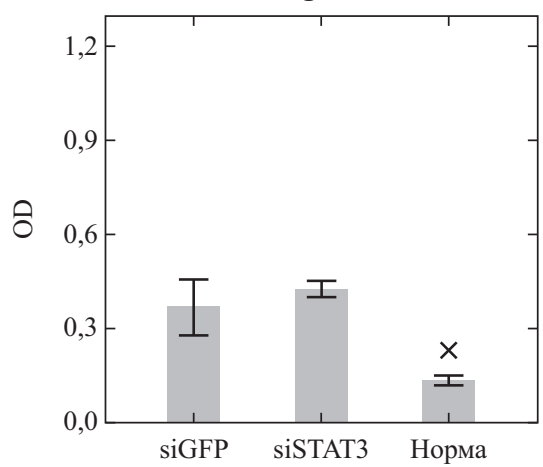

Рис. 1. Влияние комплекса siSTAT3/LTP на гиперреактивность бронхов и уровни аллерген-специфических антител в сыворотке крови A - дизайн исследования; Б - уровни экспрессии гена Stat3 в клетках бронхоальвеолярного лаважа (БАЛ); В - гиперреактивность бронхов в ответ на возрастающие концентраџии метахолина (MX), измеренная как удельная сопротивляемость бронхов; Г-уровни аллерген-спещифических антител классов IgE, IgG2a и IgG1 в сыворотке крови.

Представлены средние значение \pm стандартная ошибка; $n=7 ; \times-$ статистически значимо отличается от siGFP по U-критерию Манна-Уитни. 

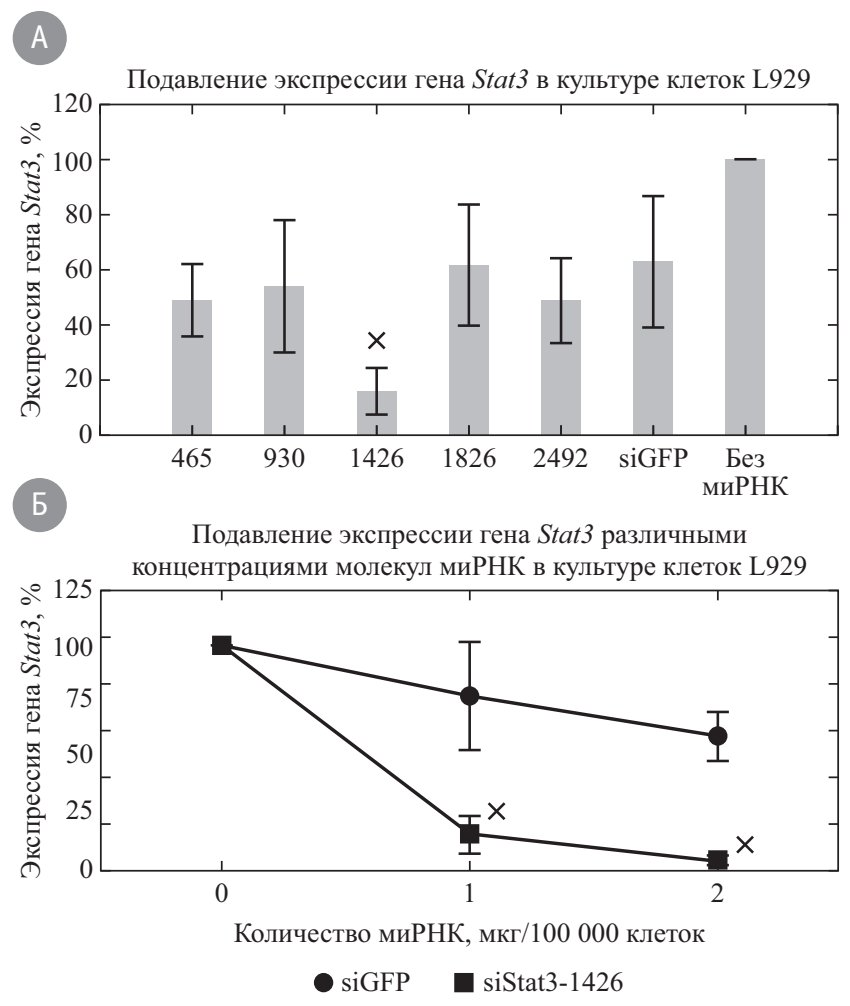

Рис. 2. Подавление экспрессии гена Stat3 молекулами миРНК в экспериментах in vitro

A - скрининг активности молекул миРНК на культуре клеток L929; Б - супрессия экспрессии гена Stat 3 с помощью различных кониентраџий миРНК siSTAT3-1426 в культуре клеток L929. Клетки в количестве 100 тыс. трансфеиировали смесью 1 мкг миРНК и коммерческого реагента Lipofectamine 2000, после чего определяли активность Stat3 методом количественной ПЦР. В качестве контроля клетки трансфецировали неспецифическими миРНК против гена Gfp (siGFP). Результаты выражали в \% относительно активности Stat3 в необработанных клетках. Представлены средние значения \pm стандартная ошибка; $n=5 ; \times-$ статистически значимо отличается от siGFP по U-критерию Манна-Уитни.

Данное программное обеспечение рассчитывает термодинамические параметры гибридизации РНК-олигонуклеотидов, а также предсказывает их свободную энергию связывания с мРНК-мишенью. Для синтеза было выбрано 5 вариантов миРНК. Выбор этих вариантов обусловлен следующими критериями: 1) предсказанная теоретическая эффективность $\geq 90 \%$; 2) сходство с другими генами в геноме мыши $\leq 84 \%$, что необходимо для нивелирования off-target-эффектов.

Представленные варианты были синтезированы и очищены, проведен скрининг биологической активности в экспериментах in vitro на культуре клеток L929, так как эти клетки конститутивно экспрессируют Stat3. Для этого 100 тыс. клеток трансфецировали 1 мкг миРНК в смеси с коммерческим реагентом Lipofectamine 2000, после чего оценивали активность целевого гена методом количественной ПЦР. Было показано, что один вариант миРНК (siSTAT3-1426) статистически значимо на $75 \%$ снижал экспрессию Stat3 в клетках по сравнению с неспецифическими миРНК (siGFP) (рис. 2А). При этом отмечен дозозависимый эффект от применения siSTAT3-1426 (рис. 2Б). Эти данные свидетельствуют о сиквенс-специфическом подавлении экспрессии Stat3.

Комплекс миРНК и пептида-носителя подавляет активность гена Stat3 in vitro

В качестве носителя для созданной молекулы миРНК против гена Stat3 (siSTAT3-1426) мы использовали созданный ранее катионный дендримерный пептид LTP. Этот пептид способен доставлять нуклеиновые кислоты (включая миРНК) в различные типы клеток млекопитающих. Для эффективной доставки необходим 12,5-кратный избыток LTP в комплексе миРНК/пептид [16]. В отдельных экспериментах in vitro была изучена способность комплекса siSTAT3/LTP подавлять экспрессию Stat3 в клетках L929. Для этого в культуру клеток вносили siSTAT3/LTP в различных концентрациях, инкубировали 1 сут и измеряли экспрессию Stat3 методом количественной ПЦР. Как оказалось комплекс siSTAT3/ LTP в количестве 4 мкг (по миРНК) на 100 тыс. клеток статистически значимо супрессирует экспрессию Stat3 в 3,7 раза в сравнении с комплексом siGFP/LTP, в состав которого включены неспецифические молекулы миРНК (рис. 3A).

Также изучена способность комплекса siSTAT3/LTP супрессировать экспрессию Stat3 в Th17-клетках. Для этого Th0-клетки были выделены из селезенок мышей, дифференцированы в Th17-клетки в присутствии антиCD28-антител, ИЛ-6, ТФР $\beta$ в течение 3 сут. В ходе дифференцировки клетки были обработаны молекулами миРНК siSTAT3-1426 в комплексе с различными трансфекционными агентами (Lipofectamine 2000 и LTP). В клетках, обработанных комплексом siSTAT3-1426 с LTP, мы выявили 2-кратное снижение уровня экспрессии мРНК Stat3 и 5-7-кратное снижение уровня экспрессии мРНК Ill7a. При этом внесение в культуру клеток комплекса siSTAT3-1426 и Lipofectamine 2000 не приводило к изменению экспрессии этих генов (рис. 3Б). Учитывая, что комплекс молекул siSTAT3-1426 и пептида LTP в массовом соотношении 1/12,5 способен подавлять экспрессию генов Stat3 и Ill $7 a$ в лимфоцитах, его использовали в последующих исследованиях in vivo на модели нейтрофильной БА у мышей.

\section{Комплекс миРНК и пептида-носителя подавляет активность гена Stat3 in vivo и снижает нейтрофильное воспаление в легких}

В экспериментах in vivo мы использовали ранее созданную модель нейтрофильной БА, которая характеризовалась повышенным уровнем аллерген-специфических IgE-антител, развитием гиперреактивности бронхов и нейтрофильным воспалением легких. В ходе исследования животным с индуцированной нейтрофильной БА проводили ингаляции комплексом молекул siSTAT3-1426 и пептида LTP (siSTAT3/LTP). В качестве контроля осуществляли ингаляции аналогичной дозой комплекса, содержащего неспецифические молекулы миРНК siGFP. После курса ингаляций у мышей оцени- 
Рис. 3. Подавление экспрессии гена Stat3 молекулами миРНК в комплексе с пептидом LTP в экспериментах in vitro

A - подавление экспрессии гена Stat 3 комплексом siSTAT3/LTP на культуре клеток L929. Клетки в количестве 100 тыс. трансфецировали различными количествами комплекса siSTAT3/LTP или siGFP/LTP (в качестве отрицательного контроля). Через 1 сут определяли активность Stat3 методом количественной ПЦР. Результаты нормализовали относительно экспрессии гена Hрrt и выражали в виде RQ. Представлены средние значения \pm стандартная ошибка; $n=4 ; \times-$ статистически значимо отличается от siGFP по U-критерию Манна-Уитни; Б - подавление экспрессии гена Stat3 комплексом siSTAT3/ LTP в Th17-клетках. Th0-клетки выделены из селезенок мышей, дифференцированы в Th17-клетки в течение 3 сут. В ходе дифференцировки клетки были обработаны молекулами миРНК sіSTAT3-1426 в комплексе с различными трансфекционными агентами (Lipofectamine 2000 и LTP). Анализировали лизаты клеток методом количественной ПЦР. Результаты нормализовали относительно экспрессии гена «домашнего хозяйства» Actb и выражали в виде RQ. Представлены средние значения \pm стандартная ошибка; $n=3$; $\times$ - статистически значимо отличается от «Без вектора» по U-критерию Манна-Уитни.
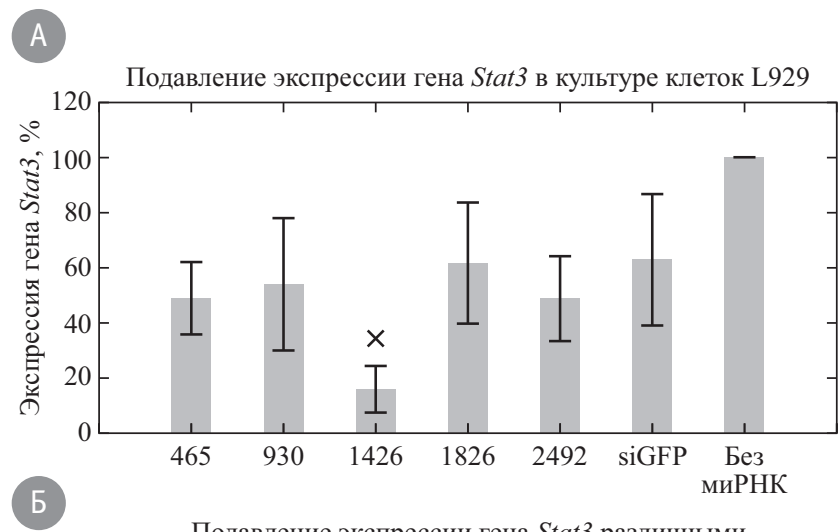

Подавление экспрессии гена Stat3 различными концентрациями молекул миРНК в культуре клеток L929

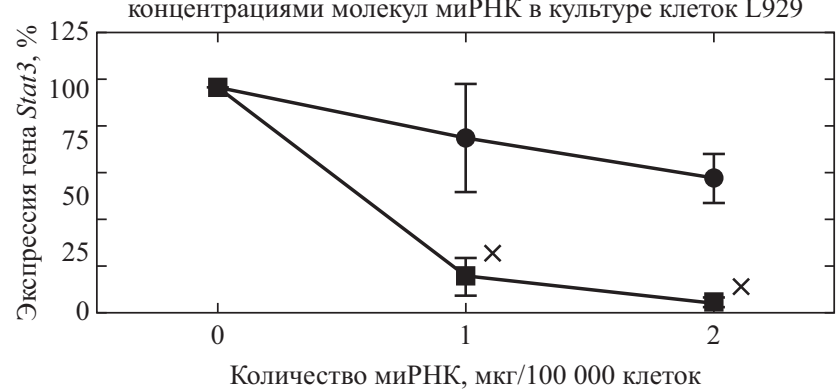

- siGFP siStat3-1426
Общее количество клеток

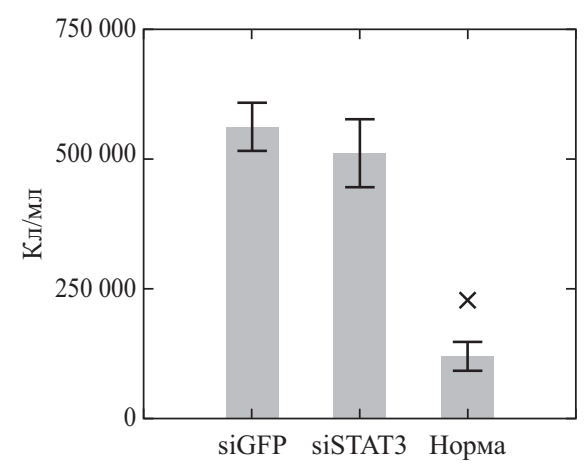

Эозинофилы

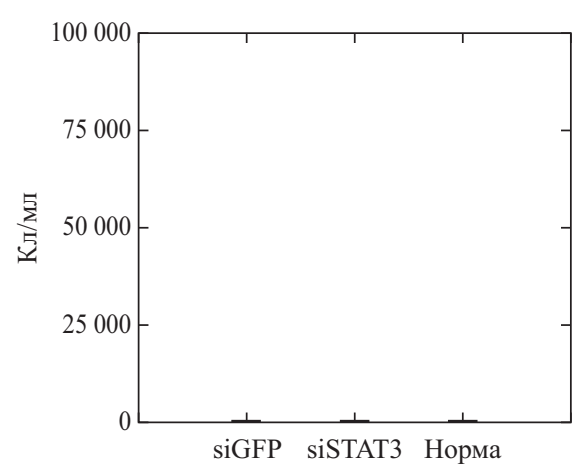

Макрофаги

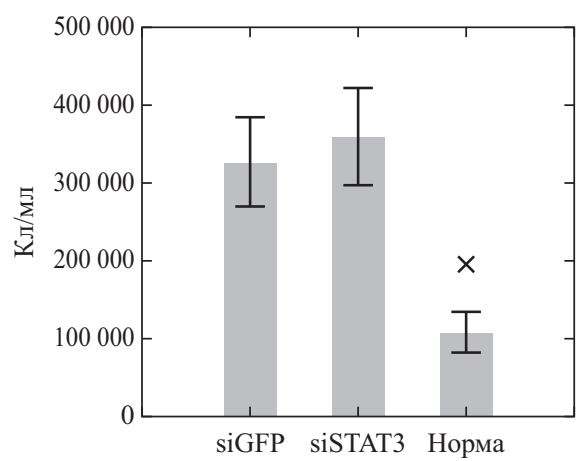

Лимфоциты

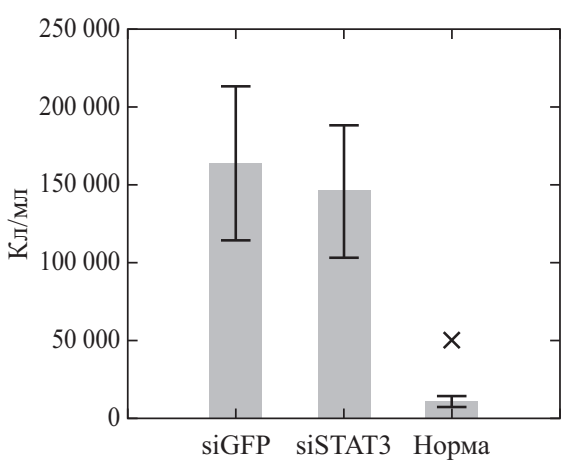

Рис. 4. Клеточный состав бронхоальвеолярного лаважа (БАЛ)

Представлены средние значения количества клеток в 1 мл БАЛ личается от siGFP по U-критерию Манна-Уитни. 
A
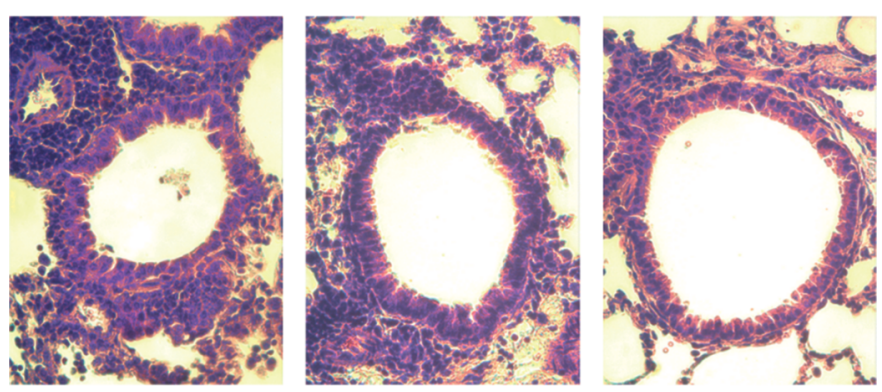

(5)
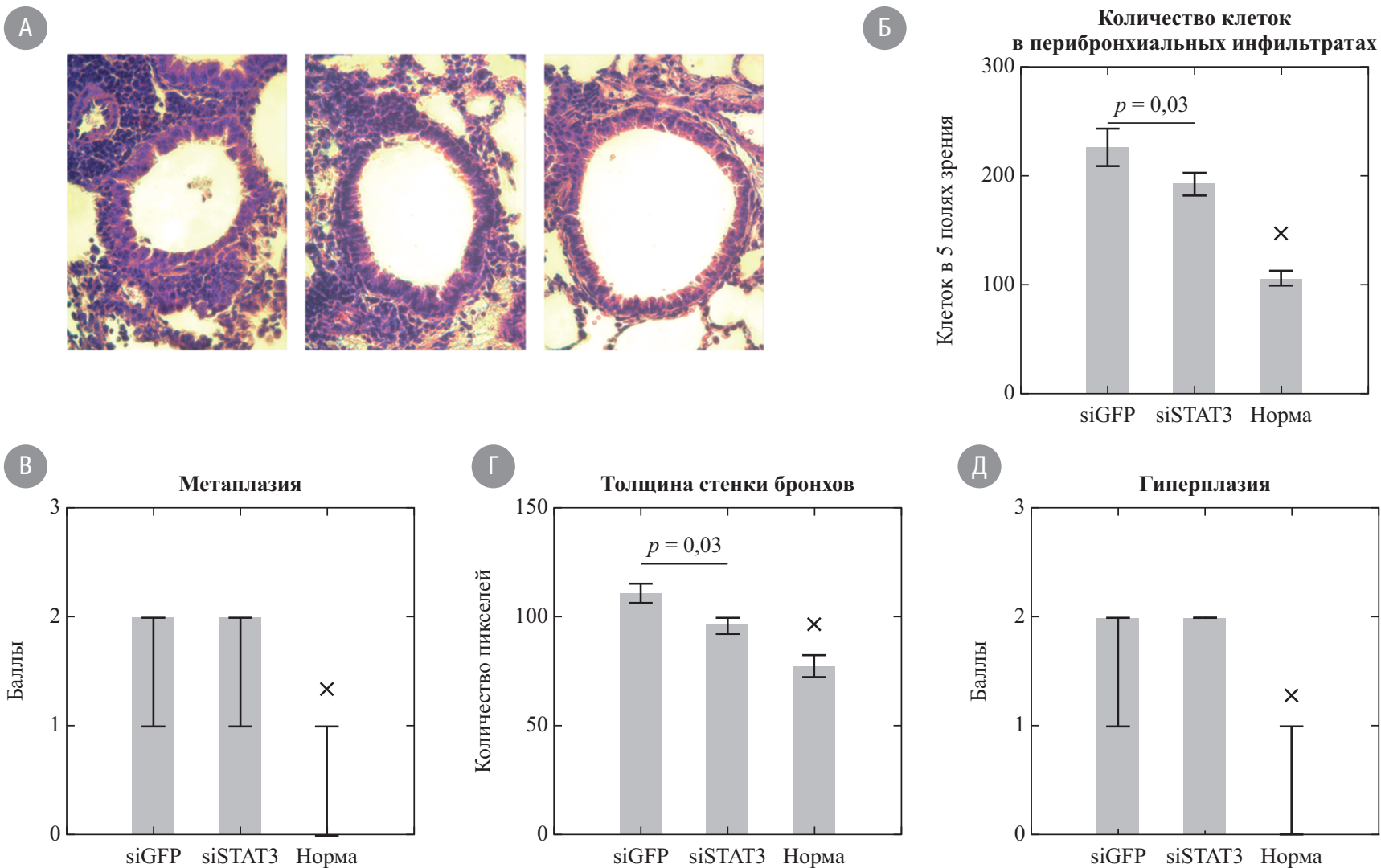

Рис. 5. Гистологические изменения в ткани легких

A - микрофотографии ткани легких после окраски гематоксилином и эозином при увеличении в 400 раз, демонстрирующие выраженность перибронхиальной инфильтрации и утолщчение бронхиального эпителия; Б-количество клеток в перибронхиальном инфильтрате; определяли количество клеток в 5 полях зрения; В - для оиенки выраженности патологических процессов в дьхательных путях использовался полуколичественный метод оченки после дифференцированной окраски срезов органа гематоксилином и эозином. Выраженность признаков воспаления оценивали в баллах по следующей шкале: 0 - отсутствует; 1 - легкая; 2 - умеренная; 3 - тяжелая. Представлена медиана \pm интерквартильный размах; $n=7 ;$ для статистического анализа применялся непараметрический критерий Краскела-Уоллиса; Г- толщчна эпителия бронхов; измеряли толщину бронхиального эпителия в пикселях с использованием микрофотографий ткани легкого при увеличении в 200 раз и программного обеспечения Altaті Stидіо. Анализировали 5 субсегментарных бронхов у каждого экспериментального животного. Представлены средние значения \pm стандартная ошибка средней; $n=7 ; \times$ - статистически значимо отличается от siGFP по U-критерию Манна-Уитни.

вали степень выраженности основных проявление БА: уровень аллерген-специфических антител, изменение гиперреактивности бронхов, определяли клеточный состав БАЛ и выраженность гистопатологических изменений в легких.

Ингаляции комплексом, содержащим siSTAT3 и LTP, приводили к подавлению экспрессии гена Stat3 на 50 \% в клетках БАЛ $(p<0,05)$ по сравнению с мышами, получавшими неспецифические молекулы siGFP (рис. 1Б) Изучение ГРБ показало, что у животных, получавших комплекс, состоящий из siSTAT3 и пептида-носителя LTP, не происходило изменения удельной сопротивляемости бронхов в сравнении с мышами, которым ингалировали комплекс, содержащий неспецифические миРНК; при этом ГРБ была значительно выше, чем в группе интактных животных (рис. 1В).

Аллерген-специфические антитела классов $\operatorname{IgE}$, $\operatorname{IgG} 2 \mathrm{a}$ и IgG1 детектировались в обеих экспериментальных группах животных, что свидетельствует о развитии гуморального иммунного ответа на аллер- ген у животных. При этом ингаляционное введение комплекса, содержащего siSTAT3, не влияло на уровень IgE- и IgG1-антител в сравнении с использованием siGFP. Это свидетельствует об отсутствии влияния супрессии гена Stat3 на формирование Th2-иммунного ответа. Мы также изучили изменение уровня IgG2aантител в сыворотке крови, который является маркером Th1-иммунного ответа. Обнаружено увеличение уровня IgG2-антител у животных, получавших ингаляции SiSTAT3, в сравнении с мышами, получившими siGFP (рис. 1Г).

При индукции у мышей нейтрофильной БА происходило 5-кратное увеличение общего количества клеток в образцах БАЛ по сравнению с интактными животными. Такое увеличение происходило за счет инфильтрации легких макрофагами, лимфоцитами и нейтрофилами. При этом увеличения числа эозинофилов не происходило. Это свидетельствует о развитии нейтрофильного воспаления в легких. Ингаляции комплексом siSTAT3/LTP приводило к значительному, 3-кратному 
уменьшению количества нейтрофилов в сравнении с мышами, получавшими ингаляции неспецифическими молекулами миРНК (siGFP) (рис. 4).

Гистологический анализ легких не выявил статистически значимого уменьшения выраженности инфильтрации после курса ингаляций комплексом siSTAT3/LTP в сравнении с комплексом siGFP/LTP. OTмечена лишь тенденция к уменьшению числа клеток в перибронхиальных инфильтратах на $20 \%(p=0,18)$ (рис. 5А, 5Б). Также не выявлено уменьшения выраженности гиперплазии и метаплазии бронхиального эпителия у животных, получавших siSTAT3/LTP (рис. 5В). Однако у животных, ингалированных комплексом siSTAT3/LTP, снижалась толщина стенок бронхов (рис. 5Г).

Изучена экспрессия провоспалительных цитокинов в клетках БАЛ. Было показано, что подавление экспрессии гена Stat3 молекулами миРНК приводит к снижению экспрессии генов Th17-цитокинов (в 2,1 раза для $I l 17 a$, в 4,8 раза для Ill7f). В то же время не наблюдалось выраженного изменения в экспрессии генов Th2цитокина - Il4 и Th1-цитокина - Ifng (рис. 6).

\section{Обсуждение}

В данной работе мы показали, что локальное подавление экспрессии гена Stat3 молекулами миРНК уменьшает воспаление в легких и ремоделирование респираторного тракта у мышей с индуцированной БА. Путем аэрозольной провокации смесью аллергена и ЛПС у животных воссоздавались следующие патологические изменения: воспаление легких, характеризующееся увеличением числа нейтрофилов, макрофагов и лимфоцитов в дыхательных путях, гиперреактивность и ремоделирование бронхов. Указанные патологические изменения формировались по Тh17-зависимому механизму [18], о чем свидетельствует увеличение экспрессии генов Stat3 (рис. 1Б), Il17a и Il17f (рис. 6) в клетках БАЛ. Соответственно, супрессия экспрессии Stat3 молекулами миРНК приводила к подавлению Th17иммунного ответа, о чем свидетельствует значительное уменьшение экспрессии Ill7a и Ill7f в клетках БАЛ. При этом экспрессия гена Ifng, являющегося маркером Th1-иммунного ответа, и гена Il4, который является маркером Th2-иммунного ответа, не изменялись после ингаляционного введения миРНК (рис. 6).

Примечательно, что подавление экспрессии Stat3 приводило к уменьшению содержания нейтрофилов в БАЛ в 3 раза, в то время как содержание макрофагов и лимфоцитов не изменялось (см. рис. 4). Это объясняется тем, что Тh17-клетки и секретируемые ими цитокины (ИЛ-17А и ИЛ-17F) участвуют в привлечении нейтрофилов в участок воспаления, в данном случае в легкие $[21,22]$. В то же время уменьшение нейтрофильного воспаления легких не приводило к снижению сопротивляемости бронхов; этот показатель оставался на относительно высоком уровне (см. рис. 1В). По всей видимости, нейтрофилы не вносят значимого вклада в развитие гиперактивности бронхов.
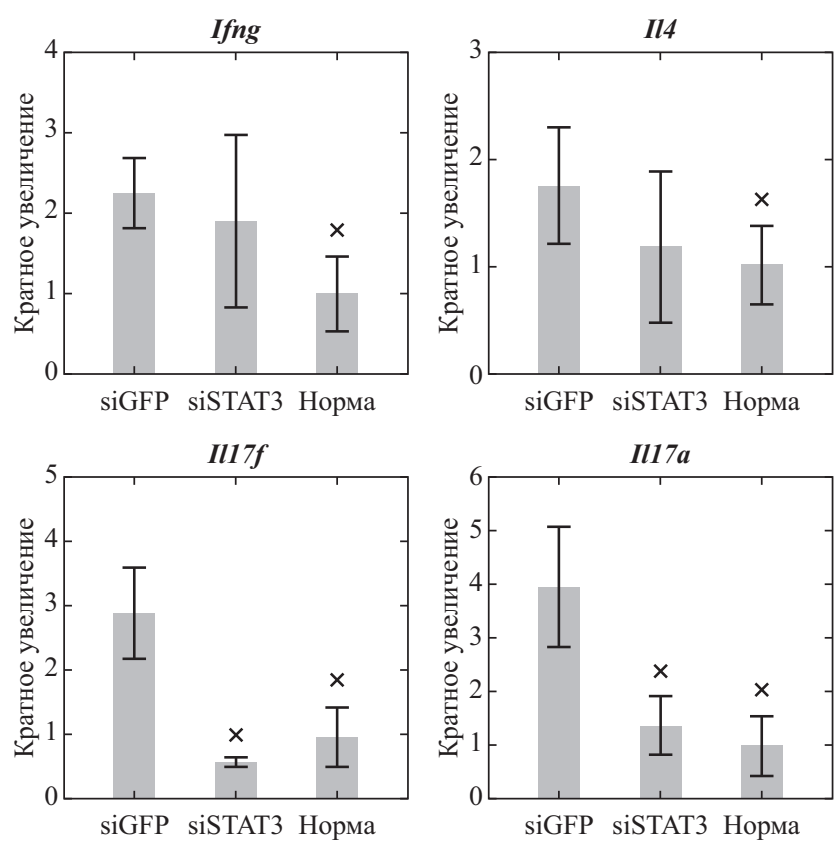

Рис. 6. Изменение экспрессии цитокинов в клетках бронхоальвеолярного лаважа

Представлены средние значения относительной экспрессии генов ичитокинов Ifng, Il4, Il17a и Il17f \pm стандартная ошибка.

Уровень экспрессии гена в группе «Норма» был принят за 1; $n=7 ; \times-$ статистически значимо отличается от siGFP по U-критерию Манна-Уитни.

Дополнительно мы оценили гистологические изменения в ткани легких, которые показали, что супрессия экспрессии Stat3 и уменьшение нейтрофильного воспаления частично нивелируют признаки ремоделирования бронхов. В частности, происходило восстановление толщины стенок бронхов, но при этом такие признаки ремоделирования, как метаплазия и гиперплазия бронхиального эпителия, не уменьшались после блокирования гена Stat3. Высокий уровень метаплазии и гиперплазии эпителия объясняет повышенную гиперреактивность бронхов у мышей, получавших миРНК.

Были изучены изменения уровней аллерген-специфических IgE-, IgG1- и IgG2а-антител после подавления экспрессии Stat3 молекулами миРНК. Супрессия этого гена не приводила к изменению уровней IgEи IgG1-антител, являющихся маркерами Th2-иммунного ответа [23]. В то же время происходило увеличение уровня IgG2а-антител, что свидетельствует о переключении иммунного ответа в сторону Th1-типа [23] (см. рис. 1Г). Антитела классов IgE и IgG1 у мышей важны для развития ГРБ $[24,25]$. Учитывая, что уровни этих антител не уменьшаются после супрессии Stat3, это может объяснять отсутствие благоприятного эффекта молекул миРНК на сопротивляемость бронхов.

Известно, что молекулы миРНК самопроизвольно не проникают к месту действия - в цитоплазму клеток-мишеней $[15,26]$. Для этого молекулы миРНК водили аэрозольно в комплексе с катионным пептидом-носителем LTP [16]. Ранее нами было показано, что данный пептид 
способен доставлять нуклеиновые кислоты в широкий спектр клеток млекопитающих, включая лимфоциты [16]. В данном исследовании мы получили популяцию Th17-клеток мышей и в эксперименте in vitro обработали ее комплексом молекул миРНК и LTP, что привело к подавлению экспрессии генов Stat3 и Il17a (рис. 3). Это доказывает способность пептида LTP доставлять молекулы миРНК в Th17-клетки и негативно регулировать экспрессию провоспалительных цитокинов.

Полученные нами результаты сходны с ранее проведенными исследованиями других авторов. В работе H. Lim и соавт. [27] осуществлен нокаут гена Stat3 в Т-клетках мышей с последующей индукцией у них экспериментальной БА. Методом проточной цитометрии показано уменьшение количества Th17-клеток в ткани легких и в лимфатических узлах после нокаута гена Stat3, при этом количество Th1- и Th2-клеток увеличивалось [27]. Мы также наблюдали супрессию Th17-иммунного ответа в легких после подавления активности гена Stat3 молекулами миРНК (рис. 6). Важно отметить, что инактивация гена Stat3 в Т-клетках не приводила к уменьшению уровня инфильтрации легких провоспалительными клетками [27]. Это согласуется с полученными нами данными. Анализ клеточного состава БАЛ (см. рис. 4) и гистологический анализ ткани легких (см. рис. 5Б) показали отсутствие уменьшения количества инфильтрирующих легкие клеток после подавления активности Stat3 молекулами миРНК. При этом мы обнаружили 3-кратное уменьшение числа нейтрофилов в образцах БАЛ (см. рис. 4), в то же время в работе H. Lim и соавт. [27] не проведена дифференцировка клеток, инфильтрирующих ткань легких, что не позволяет судить об изменении уровня нейтрофилии после нокаута гена Stat3. Также авторы показали что инактивация гена Stat3 в Т-клетках приводила к незначительному уменьшению гиперсекреции слизи эпителием бронхов [27]. Это согласуется с полученными нами результатами, подавление экспрессии гена Stat3 молекулами миРНК не влияло на выраженность метаплазии и гиперплазии эпителия бронхов (см. рис. 5В).

В еще одном исследовании [28] авторами был осуществлен нокаут гена Stat3 в эпителиальных клетках, после чего у мышей моделировалось экспериментальная БА. У животных с инактивированным геном наблюдались снижение ГРБ, уменьшение инфильтрации легких эозинофилами и Th2-клетками, а также снижался уровень продуцируемых ими цитокинов (ИЛ-4, -5, -13). При этом уровень Тh1-цитокина интерферона- $\gamma$ оставался неизменным. Уменьшение количества Th2-клеток в легких авторы связывают со снижением уровня хемокина TARC, являющегося аттрактантом этих клеток. Сходные результаты были получены при использовании ингибиторов киназ, вовлеченных в STAT3-сигнальный путь [28]. В отличие от исследования [28], мы не выявили влияния супрессии гена Stat3 на уровень Th2цитокинов в легких (рис. 6), что, скорее всего, связано с различиями в используемых моделях воспаления легких. Авторы исследования [28] индуцировали экспериментальную БА путем активации Тh2-иммунного ответа, сопряженного с инфильтрацией легких эозинофилами, в то же время в нашем исследовании мы индуцируем нейтрофильное воспаление легких, которое развивается по Тh17-зависимому механизму.

\section{Заключение}

Таким образом, был создан комплекс, состоящий из молекул миРНК против гена Stat3 и пептида-носителя LTP, ингаляции которым приводят к уменьшению Th17-зависимого нейтрофильного воспаления легких. Применение созданного комплекса может быть многообещающим подходом к терапии нейтрофильной кортикостероид-резистентной БА.

Вклад авторов. Концепция и дизайн исследования - Шиловский И.П., Хаитов М.Р.; сбор и обработка материала - Юмашев К.В., Никольский А.А., Вишнякова Л.И., Барвинская Е.Д., Ковчина В.И., Туренко В.Н., Корнеев А.В., Каганова М.М.; статистическая обработка данных - Никольский А.А., Вишнякова Л.И., Барвинская Е.Д., Ковчина В.И.; написание текста - Шиловский И.П., Никольский А.А.; редактирование - Брылина В.Е., Никонова А.А.; утверждение окончательного варианта статьи - Козлов И.Б., Кофиади И.А., Петухова О.А.; ответственность за целостность всех частей статьи - Сергеев И.В., Маерле А.В, Кудлай Д.А.

\section{- Литература}

1. GINA Committee. Global Initiative for Asthma. Global Strategy for Asthma Management and Prevention. 2020. URL: https://ginasthma.org/wp-content/uploads/2020/04/GINA-2020-Appendix_final-wms.pdf (date of access October 14, 2021)

2. Soriano J.B., Abajobir A.A., Abate K.H., Abera S.F. et al Global, regional, and national deaths, prevalence, disability-adjusted life years, and years lived with disability for chronic obstructive pulmonary disease and asthma, 1990-2015: a systematic analysis for the Global Burden of Disease Study 2015. Lancet Respir. Med. 2017; 5: 691-706. DOI: http://doi.org/10.1016/S2213-2600(17) 30293-Х

3. Авдеев С.Н., Ненашева Н.М., Жуденков К.В., Петраковская В.А., Изюмова Г.В. Распространенность, заболеваемость, фенотипы и другие характеристики тяжелой бронхиальной астмы в Российской Федерации. Пульмонология. 2018; 28: 341-58. DOI: http://doi.org/10.18093/0869-0189-2018-28-3-341-358
4. Moote W., Kim H., Ellis A.K. Allergen-specific immunotherapy. Allergy Asthma Clin. Immunol. 2018; 14: 1-10. DOI: http://doi. org/10.1186/s13223-018-0282-5

5. Павлова К.С., Курбачева О.М., Галицкая М.А., Смирнов Д.С. Актуальные представления о механизмах аллерген-специфической иммунотерапии, потенциальных маркерах эффективности и путях совершенствования. Российский аллергологический журнал. 2017; 14: 5-17. DOI: http://doi.org/10.36691/RJA290

6. Corren J., Lemanske R.F., Hanania N.A., Korenblat P.E., Parsey M.V., Arron J.R., Harris J.M., Scheerens H., Wu L.C., Su Z., Mosesova S., Eisner M.D., Bohen S.P., Matthews J.G. Lebrikizumab treatment in adults with asthma. N. Engl. J. Med. 2011; 365: 1088-98. DOI: http://doi.org/10.1056/NEJMoa1106469

7. Wenzel S.E. Asthma phenotypes: the evolution from clinical to molecular approaches. Nat. Med. 2012; 18: 716-25. DOI: http://doi. org/10.1038/nm.2678 
8. Seys S.F., Lokwani R., Simpson J.L., Bullens D.M.A. New insights in neutrophilic asthma. Curr. Opin. Pulm. Med. 2019; 25: 11320. DOI: http://doi.org/10.1097/MCP.0000000000000543

9. Liu W., Liu S., Verma M., Zafar I., Good J.T., Rollins D., Groshong S., Gorska M.M., Martin R.J., Alam R. Mechanism of TH2/ TH17-predominant and neutrophilic TH2/TH17-low subtypes of asthma. J. Allergy Clin. Immunol. 2017; 139: 1548-58. DOI: http://doi org/10.1016/j.jaci.2016.08.032

10. Chaudhry A., Rudra D., Treuting P., Samstein R.M., Liang Y., Kas A., Rudensky A.Y. CD4+ regulatory T cells control Th17 responses in a STAT3-dependent manner. Science. 2009; 326: 986-91. DOI: $\mathrm{http}: / /$ doi.org/10.1126/science.1172702

11. Halwani R., Sultana A., Vazquez-Tello A., Jamhawi A., AlMasri A.A., Al-Muhsen S. Th-17 regulatory cytokines IL-21, IL-23, and IL-6 enhance neutrophil production of IL-17 cytokines during asthma. J. Asthma. 2017; 54: 893-904. DOI: http://doi.org/10.1080/0 2770903.2017.1283696

12. Shilovskiy I.P., Nikolskii A.A., Kurbacheva O.M., Khaitov M.R. Modern view of neutrophilic asthma molecular mechanisms and therapy. Biochemistry (Mosc). 2020; 85: 854-68. DOI: http://doi. org $/ 10.1134 / \mathrm{S} 0006297920080027$

13. Saw P.E., Song E.W. siRNA therapeutics: a clinical reality. Sci. China Life Sci. 2020; 63: 485-500. DOI: http://doi.org/10.1007/ s11427-018-9438-y

14. Nikam R.R., Gore, K.R. Journey of siRNA: clinical developments and targeted delivery. Nucleic Acid Ther. 2018; 28: 209-24. DOI: http://doi.org/10.1089/nat.2017.0715

15. Koloskova O.O., Nosova A.S., Sebyakin Y.L., Ilyukhina A.A. Shilovskiy I.P., Khaitov M.R. Liposomal siRNA delivery systems (review). Russ. J. Biopharm. 2017; 9: 3-10.

16. Kozhikhova K.V, Andreev S.M., Shilovskiy I.P., Timofeeva A.V, Gaisina A.R., Shatilov A.A., Turetskiy E.A., Andreev I.M., Smirnov V.V, Dvornikov A.S., Khaitov M.R. A novel peptide dendrime LTP efficiently facilitates transfection of mammalian cells. Org. Biomol. Chem. 2018; 16: 8181-90. DOI: http://doi.org/10.1039/c8ob02039f

17. Kanasty R., Dorkin J.R., Vegas A., Anderson D. Delivery materials for siRNA therapeutics. Nat. Mater. 2013; 12: 967-77. DOI: http://doi.org/10.1038/nmat3765

18. Шиловский И.П., Никольский А.А., Ковчина В.И., Болотова С.И., Вишнякова Л.И., Соколова А.Р., Барвинская Е.Д., Хаитов М.Р. Активация Th17-иммунного ответа при экспериментальной нейтрофильной бронхиальной астме у мышей. Иммунология. 2019; 40: 5-15. DOI: http://doi.org/10.24411/0206-4952-2019-16001
19. Lu Z.J., Mathews D.H. OligoWalk: an online siRNA design tool utilizing hybridization thermodynamics. Nucleic Acids Res. 2008; 36: 104-8. DOI: http://doi.org/10.1093/nar/gkn250

20. Shilovskiy I.P., Sundukova M.S., Babakhin A.A., GaisinaA.R., Maerle A.V., Sergeev I.V., Nikolskiy A.A., Barvinckaya E.D., Kovchina V.I., Kudlay D.A., Nikonova A.A., Khaitov M.R. Experimental protocol for development of adjuvant-free murine chronic model of allergic asthma. J. Immunol. Methods. 2019; 468: 10-9. DOI: http:/ doi.org/10.1016/j.jim.2019.03.002

21. Chang H.S., Lee T.H., Jun J.A., Baek A.R., Park J.S., Koo S.M., Kim Y.K., Lee H.S., Park C.S. Neutrophilic inflammation in asthma: mechanisms and therapeutic considerations. Expert Rev Respir. Med. 2017; 11: 29-40. DOI: http://doi.org/10.1080/1747634 8.2017 .1268919

22. Newcomb D.C., Peebles R.S. Th17-mediated inflammation in asthma. Curr. Opin. Immunol. 2013; 25: 755-760. DOI: http://doi. org/10.1016/j.coi.2013.08.002

23. Steinke J.W., Borish L. Th2 cytokines and asthma. Interleukin-4: its role in the pathogenesis of asthma, and targeting it for asthma treatment with interleukin-4 receptor antagonists. Respir. Res. 2001; 2 66-70. DOI: http://doi.org/10.1186/rr40

24. Miyajima I., Dombrowicz D., Martin T.R., Ravetch J.V, Kinet J.P., Galli S.J. Systemic anaphylaxis in the mouse can be mediated largely through IgG1 and Fc gammaRIII. Assessment of the cardiopulmonary changes, mast cell degranulation, and death associated with active or IgE- or IgG1-dependent passive anaphylaxis. J. Clin. Invest. 1997; 99: 901-14. DOI: http://doi.org/10.1172/ JCI119255

25. Oettgen H.C., Martin T.R., Wynshaw-Boris A., Deng C., Drazen J.M., Leder P. Active anaphylaxis in IgE-deficient mice. Nature. 1994; 370: 367-70. DOI: http://doi.org/10.1038/370367a0

26. Juliano R.L. The delivery of therapeutic oligonucleotides. Nucleic Acids Res. 2016; 44: 6518-48. DOI: http://doi.org/10.1093/ nar/gkw236

27. Lim H., Cho M., Choi G., Na H., Chung Y. Dynamic control of Th2 cell responses by STAT3 during allergic lung inflammation in mice. Int. Immunopharmacol. 2015; 28: 846-53. DOI: http://doi. org/10.1016/j.intimp.2015.03.051

28. Simeone-Penney M.C., Severgnini M., Tu P., Homer R.J., Mariani T.J., Cohn L., Simon A.R. Airway epithelial STAT3 is required for allergic inflammation in a murine model of asthma. J. Immunol. 2007; 178: 6191-9. DOI: http://doi.org/10.4049/jimmunol.178.10.6191

\section{- References}

1. GINA Committee. Global Initiative for Asthma. Global Strategy for Asthma Management and Prevention. 2020. URL: https://ginasthma.org/wp-content/uploads/2020/04/GINA-2020-Appendix final-wms.pdf (date of access October 14, 2021)

2. Soriano J.B., Abajobir A.A., Abate K.H., Abera S.F., et al. Global, regional, and national deaths, prevalence, disability-adjusted life years, and years lived with disability for chronic obstructive pulmonary disease and asthma, 1990-2015: a systematic analysis for the Global Burden of Disease Study 2015. Lancet Respir. Med. 2017; 5: 691-706. DOI: http://doi.org/10.1016/S2213-2600(17)30293-X

3. Avdeev S.N., Nenasheva N.M., Zhudenkov K.V., Petrakovskaya V.A., Izyumova G.V. Prevalence, morbidity, phenotypes and other characteristics of severe bronchial asthma in Russian Federation. Pul'monologiya. 2018; 28: 341-58. DOI: http://doi org/10.18093/0869-0189-2018-28-3-341-358 (in Russian)

4. Moote W., Kim H., Ellis A.K. Allergen-specific immunotherapy. Allergy Asthma Clin. Immunol. 2018; 14: 1-10. DOI: http://doi. org/10.1186/s13223-018-0282-5

5. Pavlova K.S., Kurbacheva O.M., Galitskaya M.A., Smirnov D.S. Actual conception of allergen-specific immunotherapy mechanisms, potential biomarkers of efficacy and ways of enhancement Rossiyskiy allergologicheskiy zhurnal. 2017; 14: 5-17. DOI: http:// doi.org/10.36691/RJA290 (in Russian)

6. Corren J., Lemanske R.F., Hanania N.A., Korenblat P.E., Parsey M.V., Arron J.R., Harris J.M., Scheerens H., Wu L.C., Su Z., Mosesova S., Eisner M.D., Bohen S.P., Matthews J.G. Lebrikizumab treatment in adults with asthma. N. Engl. J. Med. 2011; 365: 1088-98. DOI: http://doi.org/10.1056/NEJMoa1106469

7. Wenzel S.E. Asthma phenotypes: the evolution from clinical to molecular approaches. Nat. Med. 2012; 18: 716-25. DOI: http://doi. org $/ 10.1038 / \mathrm{nm} .2678$

8. Seys S.F., Lokwani R., Simpson J.L., Bullens D.M.A. New insights in neutrophilic asthma. Curr. Opin. Pulm. Med. 2019; 25: 11320. DOI: http://doi.org/10.1097/MCP.0000000000000543

9. Liu W., Liu S., Verma M., Zafar I., Good J.T., Rollins D., Groshong S., Gorska M.M., Martin R.J., Alam R. Mechanism of TH2 TH17-predominant and neutrophilic TH2/TH17-low subtypes of asthma. J. Allergy Clin. Immunol. 2017; 139: 1548-58. DOI: http://doi org/10.1016/j.jaci.2016.08.032

10. Chaudhry A., Rudra D., Treuting P., Samstein R.M., Liang Y., Kas A., Rudensky A.Y. CD4+ regulatory T cells control Th17 responses in a STAT3-dependent manner. Science. 2009; 326: 986-91. DOI: http://doi.org/10.1126/science.1172702

11. Halwani R., Sultana A., Vazquez-Tello A., Jamhawi A., AlMasri A.A., Al-Muhsen S. Th-17 regulatory cytokines IL-21, IL-23, and IL- 6 enhance neutrophil production of IL-17 cytokines during asthma. J. Asthma. 2017; 54: 893-904. DOI: http://doi.org/10.1080/0 2770903.2017.1283696

12. Shilovskiy I.P., Nikolskii A.A., Kurbacheva O.M., Khaitov M.R. Modern view of neutrophilic asthma molecular mechanisms and therapy. Biochemistry (Mosc). 2020; 85: 854-68. DOI: http://doi. org/10.1134/S0006297920080027

13. Saw P.E., Song E.W. siRNA therapeutics: a clinical reality Sci. China Life Sci. 2020; 63: 485-500. DOI: http://doi.org/10.1007/ s11427-018-9438-y

14. Nikam R.R., Gore, K.R. Journey of siRNA: clinical developments and targeted delivery. Nucleic Acid Ther. 2018; 28: 209-24. DOI: http://doi.org/10.1089/nat.2017.0715

15. Koloskova O.O., Nosova A.S., Sebyakin Y.L., Ilyukhina A.A., Shilovskiy I.P., Khaitov M.R. Liposomal siRNA delivery systems (review). Russ. J. Biopharm. 2017; 9: 3-10. 
16. Kozhikhova K.V, Andreev S.M., Shilovskiy I.P., Timofeeva A.V, Gaisina A.R., Shatilov A.A., Turetskiy E.A., Andreev I.M., Smirnov V.V, Dvornikov A.S., Khaitov M.R. A novel peptide dendrimer LTP efficiently facilitates transfection of mammalian cells. Org. Biomol. Chem. 2018; 16: 8181-90. DOI: http://doi.org/10.1039/c8ob02039f

17. Kanasty R., Dorkin J.R., Vegas A., Anderson D. Delivery materials for siRNA therapeutics. Nat. Mater. 2013; 12: 967-77. DOI: http://doi.org/10.1038/nmat3765

18. Shilovskiy I.P., Nikolskii A.A., Kovchina V.I., Bolotova S.I., Vishniakova L.I., Sokolova A.R., Barvinskaya E.D., Khaitov M.R. Activation of Th17-immune response in a mouse model of neutrophilic asthma. Immunologiya. 2019; 40: 5-15. DOI: http://doi. org/10.24411/0206-4952-2019-16001 (in Russian)

19. Lu Z.J., Mathews D.H. OligoWalk: an online siRNA design tool utilizing hybridization thermodynamics. Nucleic Acids Res. 2008; 36: 104-8. DOI: http://doi.org/10.1093/nar/gkn250

20. Shilovskiy I.P., Sundukova M.S., Babakhin A.A., Gaisina A.R., Maerle A.V., Sergeev I.V., Nikolskiy A.A., Barvinckaya E.D., Kovchina V.I., Kudlay D.A., Nikonova A.A., Khaitov M.R. Experimental protocol for development of adjuvant-free murine chronic model of allergic asthma. J. Immunol. Methods. 2019; 468: 10-9. DOI: http://doi.org/10.1016/j.jim.2019.03.002

21. Chang H.S., Lee T.H., Jun J.A., Baek A.R., Park J.S., Koo S.M., Kim Y.K., Lee H.S., Park C.S. Neutrophilic inflammation in asthma: mechanisms and therapeutic considerations. Expert Rev. Respir. Med. 2017; 11: 29-40. DOI: http://doi.org/10.1080/17476348.2017.1268919

\section{Сведения об авторах}

Никольский Александр Аркадьевич - мл. науч. сотр. лаб. противовирусного иммунитета ФГБУ «ГНЦ Институт иммунологии» ФМБА России, Москва, Российская Федерация

E-mail: aa.nikolskii@nrcii.ru

https://orcid.org/0000-0002-4169-0760

Шиловский Игорь Петрович - д-р биол. наук, зам. директора по науке и инновациям ФГБУ «ГНЦ Институт иммунологии» ФМБА России, Москва, Российская Федерация

E-mail: ip.shilovsky@nrcii.ru

https://orcid.org/0000-0001-5343-4230

Юмашев Кирилл Валерьевич - студент ФГБОУ ВО МГАВМиБ МВА имени К.И. Скрябина; лаборант лаб. противовирусного иммунитета ФГБУ «ГНЦ Институт иммунологии» ФМБА России, Москва, Российская Федерация

E-mail: yumashev.k.98@mail.ru

https://orcid.org/0000-0003-1544-0597

Вишнякова Людмила Ивановна - мл. науч. сотр. лаб. противовирусного иммунитета ФГБУ «ГНЦ Институт иммунологии» ФМБА России, Москва, Российская Федерация

E-mail: lyudmilochka94@mail.ru

https://orcid.org/0000-0002-3555-3268

Барвинская Екатерина Драгановна - мл. науч. сотр. лаб. противовирусного иммунитета ФГБУ «ГНЦ Институт иммунологии» ФМБА России, Москва, Российская Федерация

E-mail: ed.barvinskaya@nrcii.ru

https://orcid.org/0000-0002-9407-7054

Ковчина Валерия Ивановна - мл. науч. сотр. лаб. противовирусного иммунитета ФГБУ «ГНЦ Институт иммунологии» ФМБА России, Москва, Российская Федерация

E-mail: kvi-91@mail.ru

https://orcid.org/0000-0003-3134-5776

Корнеев Артем Викторович - студент ФГБОУ ВО МГАВМиБ MBA имени К.И. Скрябина Минсельхоза России; лаборант лаб. противовирусного иммунитета ФГБУ «ГНЦ Институт иммунологии» ФМБА России, Москва, Российская Федерация

E-mail: korneev.molekula@gmail.com https://orcid.org/0000-0003-1864-8684

Туренко Владислав Николаевич - лаборант лаб. противовирусного иммунитета ФГБУ «ГНЦ Институт иммунологии» ФМБА России, Москва, Российская Федерация

E-mail: vladislav.turenko.n@gmail.com

https://orcid.org/0000-0003-1817-0844
22. Newcomb D.C., Peebles R.S. Th17-mediated inflammation in asthma. Curr. Opin. Immunol. 2013; 25: 755-760. DOI: http://doi org/10.1016/j.coi.2013.08.002

23. Steinke J.W., Borish L. Th2 cytokines and asthma. Interleukin-4: its role in the pathogenesis of asthma, and targeting it for asthma treatment with interleukin-4 receptor antagonists. Respir. Res. 2001; 2 66-70. DOI: http://doi.org/10.1186/rr40

24. Miyajima I., Dombrowicz D., Martin T.R., Ravetch J.V, Kinet J.P., Galli S.J. Systemic anaphylaxis in the mouse can be mediated largely through IgG1 and Fc gammaRIII. Assessment of the cardiopulmonary changes, mast cell degranulation, and death associated with active or IgE- or IgG1-dependent passive anaphylaxis. J. Clin. Invest 1997; 99: 901-14. DOI: http://doi.org/10.1172/JCI119255

25. Oettgen H.C., Martin T.R., Wynshaw-Boris A., Deng C., Drazen J.M., Leder P. Active anaphylaxis in IgE-deficient mice. Nature. 1994; 370: 367-70. DOI: http://doi.org/10.1038/370367a0

26. Juliano R.L. The delivery of therapeutic oligonucleotides. Nucleic Acids Res. 2016; 44: 6518-48. DOI: http://doi.org/10.1093/nar/gkw236

27. Lim H., Cho M., Choi G., Na H., Chung Y. Dynamic control of Th2 cell responses by STAT3 during allergic lung inflammation in mice. Int. Immunopharmacol. 2015; 28: 846-53. DOI: http://doi. org/10.1016/j.intimp.2015.03.051

28. Simeone-Penney M.C., Severgnini M., Tu P., Homer R.J., Mariani T.J., Cohn L., Simon A.R. Airway epithelial STAT3 is required for allergic inflammation in a murine model of asthma. J. Immunol. 2007; 178: 6191-9. DOI: http://doi.org/10.4049/jimmunol.178.10.6191

\section{Authors' information}

Aleksandr A. Nikolskii - Junior Researcher of the Antiviral Immunity Lab., NRC Institute of Immunology, FMBA of Russia, Moscow, Russian Federation

E-mail: aa.nikolskii@nrcii.ru

https://orcid.org/0000-0002-4169-0760

Igor P. Shilovskiy - Dr.Sci., PhD, Deputy Director on Science and Innovation, NRC Institute of Immunology, FMBA of Russia, Moscow, Russian Federation

E-mail: ip.shilovsky@nrcii.ru

https://orcid.org/0000-0001-5343-4230

Kirill V. Yumashev - Student of MVA named after K.I. Skryabin Laboratory Assistant of the Antiviral Immunity Lab., NRC Institute of Immunology, FMBA of Russia, Moscow, Russian Federation

E-mail: yumashev.k.98@mail.ru

https://orcid.org/0000-0003-1544-0597

Liudmila I. Vishniakova - Junior Researcher of the Antivira Immunity Lab., NRC Institute of Immunology, FMBA of Russia, Moscow, Russian Federation

E-mail: lyudmilochka94@mail.ru

https://orcid.org/0000-0002-3555-3268

Ekaterina D. Barvinskaia - Junior Researcher of the Antivira Immunity Lab., NRC Institute of Immunology, FMBA of Russia, Moscow, Russian Federation

E-mail: ed.barvinskaya@nrcii.ru

https://orcid.org/0000-0002-9407-7054

Valeriia I. Kovchina - Junior Researcher of the Antiviral Immunity Lab., NRC Institute of Immunology, FMBA of Russia, Moscow, Russian Federation

E-mail: kvi-91@mail.ru

https://orcid.org/0000-0003-3134-5776

Artem V. Korneev - Student of MVA named after K.I. Skryabin of the MOA of Russia; Laboratory Assistant of the Antiviral Immunity Lab., NRC Institute of Immunology, FMBA of Russia, Moscow, Russian Federation

E-mail: korneev.molekula@gmail.com https://orcid.org/0000-0003-1864-8684

Vladislav N. Turenko - Junior Researcher of the Antiviral Immunity Lab., NRC Institute of Immunology, FMBA of Russia, Moscow, Russian Federation

E-mail: vladislav.turenko.n@gmail.com https://orcid.org/0000-0003-1817-0844 


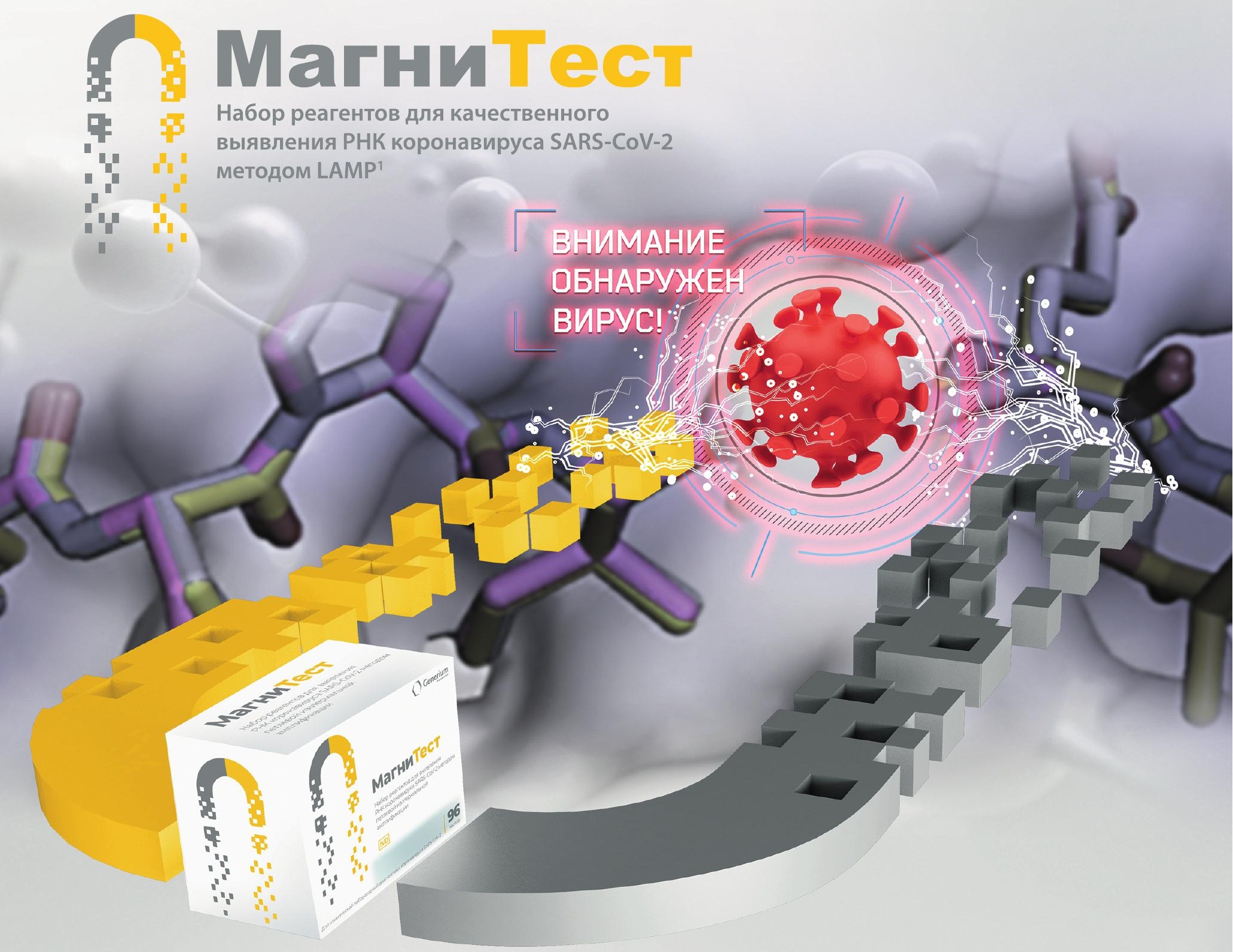

МЕТОД LAMP

МАГНИТНЫЕ ЧАСТИЦЫ

Проведение реакции при постоянной температуре 60-65을 благодаря использованию фермента Bst-полимеразы

Способствуют сокращению времени анализа ${ }^{2}$
Лизирование вируса и осаждение

PHК на магнитных частицах ${ }^{3}$

Может способствовать снижению количества ложноотрицательных результатов ${ }^{3}$

1. LAMP - Loop mediated isothermal amplification (англ.) - петлевая изотермическая амплификация. 2. Augustine, R.; Hasan, A.; Das, S.; Ahmed, R.; Mori, Y.; Notomi, T.; Kevadiya, B.D.; Thakor, A.S. Loop-Mediated Isothermal Amplification (LAMP): A Rapid, Sensitive, Specific, and Cost-Effective Point-of-Care Test for Coronaviruses in the Context of COVID-19 Pandemic. Biology 2020, 9 ,

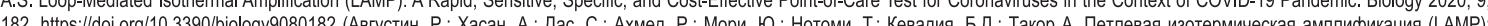
X быстрый, чувствительный, специфический и экономичный тест для лечения коронавирусов в контексте пандемии СОVD-19. Биология 2020, 9, 182.) 3. Инструкция по применению медицинского изделия для диагностики in vitro «Набор реагентов для выявления РНК коронавируса SARS-CoV-2 методом петлевой изотермальной амплификации «МагниТест»» по ТУ 21.20.23-096-26329720-2020 4. Notomi T, Okayama H, Masubuchi H, Yonekawa T, Watanabe K, Amino N, Hase T. Loop-mediated isothermal amplification of DNA. Nucleic Acids Res. 2000 Jun 15;28(12):E63. doi: 10.1093/nar/28.12.е63. PMID: 10871386; PMCID: PMC1027

Информация предназначена для медицинских специалистов. Перед применением ознакомиться с инструкцией по применению. АО «ГЕНЕРИУМ», 601125, Владимирская обл., Петушинский р-н, п. Вольгинский, ул. Заводская, строение 273.

РУ №P3Н 2021/14279 от 12 мая 2021 года 
Каганова Мария Михайловна - студент ФГБОУ ВО МГАВМиБМВА имени К.И. Скрябина; лаборант лаб. противовирусного иммунитета ФГБУ «ГНЦ Институт иммунологии» ФМБА России, Москва, Российская Федерация

E-mail: mariya.kaganova.99@mail.ru

https://orcid.org/0000-0002-2596-5779

Брылина Вера Евгеньевна - канд. вет. наук, доц. каф. иммунологии и биотехнологии ФГБОУ ВО МГАВМиБ - МВА имени К.И. Скрябина, Москва, Российская Федерация

E-mail: integrin07@rambler.ru

https://orcid.org/0000-0001-9917-2088

Никонова Александра Александровна - канд. биол. наук, науч. сотр. ФГБУ «ГНЦ Институт иммунологии» ФМБА России, Москва, Российская Федерация

E-mail: aa.nikonova@nrcii.ru

https://orcid.org/0000-0001-9610-0935

Козлов Иван Борисович - науч. сотр. лаб. молекулярной иммуногенетики ФГБУ «ГНЦ Институт иммунологии» ФМБА России,

Москва, Российская Федерация

E-mail: kozlov.nrcii@gmail.com

http://orcid.org/0000-0002-1921-7715

Кофиади Илья Андреевич - д-р биол. наук, зав. лаб. молекулярной иммуногенетики ФГБУ «ГНЦ Институт иммунологии» ФМБА России, Москва, Российская Федерация

E-mail: kofiadi@mail.ru

http://orcid.org/0000-0001-9280-8282

Сергеев Илья Викторович - канд. биол. наук, науч. сотр. ФГБУ «ГНЦ Институт иммунологии» ФМБА России, Москва, Российская Федерация

E-mail: ilya-sergeew@yandex.ru

Маерле Артем Владимирович - науч. сотр. ФГБУ «ГНЦ Институт иммунологии» ФМБА России, Москва, Российская Федерация

E-mail: maerle@yandex.ru

Петухова Ольга Андреевна - мл. науч. сотр. лаб. клинической фармакологии ФГБУ «ГНЦ Институт иммунологии» ФМБА России, Москва, Российская Федерация

E-mail: tashirik@mail.ru

https://orcid.org/0000-0002-3339-2608

Кудлай Дмитрий Анатольевич - д-р мед. наук, вед. науч. сотр лаб. персонализированной медицины и молекулярной иммунологии ФГБУ «ГНЦ Институт иммунологии» ФМБА России; проф. каф. фармакологии Института фармации ФГАОУ ВО Первый МГМУ им. И.М. Сеченова Минздрава России (Сеченовский университет), Москва, Российская Федерация

E-mail: D624254@gmail.com

https://orcid.org/0000-0003-1878-4467

Хаитов Муса Рахимович - член-корр. РАН, д-р мед. наук, проф., директор ФГБУ «ГНЦ Институт иммунологии» ФМБА России; и.о. зав. каф. иммунологии МБФ РНИМУ им. Н.И. Пирогова Минздрава России, Москва, Российская Федерация

E-mail:mr.khaitov@nrcii.ru

https://orcid.org/0000-0003-4961-9640
Mariya M. Kaganova - Student of MVA named after K.I. Skryabin of the MOA of Russia; Laboratory Assistant of the Antiviral Immunity Lab., NRC Institute of Immunology, FMBA of Russia, Moscow, Russian Federation

E-mail: mariya.kaganova.99@mail.ru https://orcid.org/0000-0002-2596-5779

Vera E. Brylina - PhD, Associate Prof. of the Immunology and Biotechnology Chair, MVA named after K.I. Skryabin of the MOA of Russia, Moscow, Russian Federation

E-mail: integrin07@rambler.ru https://orcid.org/0000-0001-9917-2088

Alexandra A. Nikonova - PhD, Researcher, NRC Institute of Immunology, FMBA of Russia, Moscow, Russian Federation

E-mail: aa.nikonova@nrcii.ru

https://orcid.org/0000-0001-9610-0935

Ivan B. Kozlov - Researcher of the Molecular Immunogenetics Lab. NRC Institute of Immunology, FMBA of Russia, Moscow, Russian Federation

E-mail: kozlov.nrcii@gmail.com

http://orcid.org/0000-0002-1921-7715

Ilya A. Kofiadi - D.Sci., PhD, Head of the Molecular Immunogenetics Lab., NRC Institute of Immunology, FMBA of Russia, Moscow, Russian Federation

E-mail: kofiadi@mail.ru

http://orcid.org/0000-0001-9280-8282

Ilya V. Sergeev - PhD, Researcher, NRC Institute of Immunology, FMBA of Russia, Moscow, Russian Federation

E-mail: ilya-sergeew@yandex.ru

Artem V. Maerle - Researcher, NRC Institute of Immunology, FMBA of Russia, Moscow, Russian Federation

E-mail: maerle@yandex.ru

Olga A. Petukhova - Junior Researcher of the Clinical Pharmacology Lab., NRC Institute of Immunology, FMBA of Russia, Moscow, Russian Federation

E-mail: tashirik@mail.ru

https://orcid.org/0000-0002-3339-2608

Dmitry A. Kudlay - MD, PhD, Leader Researcher of Laboratory of Personalized Medicine and Molecular Immunology, NRC Institute of Immunology, FMBA of Russia; Prof. of Pharmacology Chair, Institute of Pharmacy, I.M. Sechenov First Moscow State Medical University (Sechenov University), Moscow, Russian Federation

E-mail: D624254@gmail.com

https://orcid.org/0000-0003-1878-4467

Musa R. Khaitov - Corr. Member of RAS, MD, Prof., Director of NRC Institute of Immunology, of the FMBA of Russia; Deputy Head of Immunology Chair, MBF of N.I. Pirogov RNRMU of the MOH of Russia, Moscow, Russian Federation

E-mail:mr.khaitov@nrcii.ru

https://orcid.org/0000-0003-4961-9640 